\title{
Aerosol's optical and physical characteristics and direct radiative forcing during a shamal dust storm, a case study
}

\author{
T. M. Saeed ${ }^{1}$, H. Al-Dashti ${ }^{2}$, and C. Spyrou ${ }^{3}$ \\ ${ }^{1}$ Science department, College of Basic Education, Public Authority for Applied Education and Training, Al-Ardeya, Kuwait \\ ${ }^{2}$ Department of Meteorology, Directorate General of Kuwait Civil Aviation, Al-Farwanya, Kuwait \\ ${ }^{3}$ School of Physics, University of Athens, Athens, Greece \\ Correspondence to: T. M. Saeed (tm.saeed@ paaet.edu.kw)
}

Received: 28 May 2013 - Published in Atmos. Chem. Phys. Discuss.: 11 September 2013

Revised: 26 February 2014 - Accepted: 1 March 2014 - Published: 14 April 2014

\begin{abstract}
Dust aerosols are analyzed for their optical and physical properties during an episode of a dust storm that blew over Kuwait on 26 March 2003 when the military Operation Iraqi Freedom was in full swing. The intensity of the dust storm was such that it left a thick suspension of dust throughout the following day, 27 March. The synoptic sequence leading to the dust storm and the associated wind fields are discussed. Ground-based measurements of aerosol optical thickness reached 3.617 and 4.17 on 26 and 27 March respectively while the Ångstrom coefficient, $\alpha_{870 / 440}$, dropped to -0.0234 and -0.0318 . Particulate matter concentration of $10 \mu \mathrm{m}$ diameter or less, $\mathrm{PM}_{10}$, peaked at $4800 \mu \mathrm{g} \mathrm{m}^{-3}$ during dust storm hours of 26 March. Moderate Resolution Imaging Spectroradiometer (MODIS) retrieved aerosol optical depth (AOD) by Deep Blue algorithm and Total Ozone Mapping Spectrometer (TOMS) aerosol index (AI) exhibited high values. Latitude-longitude maps of $\mathrm{AOD}$ and $\mathrm{AI}$ were used to deduce source regions of dust transport over Kuwait. The vertical profile of the dust layer was simulated using the SKIRON atmospheric model. Instantaneous net direct radiative forcing is calculated at top of atmosphere (TOA) and surface level. The thick dust layer of 26 March resulted in cooling the TOA by $-60 \mathrm{Wm}^{-2}$ and surface level by $-175 \mathrm{Wm}^{-2}$ for a surface albedo of 0.35 . Slightly higher values were obtained for 27 March due to the increase in aerosol optical thickness. Radiative heating/cooling rates in the shortwave and longwave bands were also examined. Shortwave heating rate reached a maximum value of $2 \mathrm{~K} \mathrm{day}^{-1}$ between 3 and $5 \mathrm{~km}$, dropped to $1.5 \mathrm{~K} \mathrm{day}^{-1}$ at $6 \mathrm{~km}$ and diminished at $8 \mathrm{~km}$. Longwave radiation initially heated the lower atmosphere by a maximum
\end{abstract}

value of $0.2 \mathrm{~K} \mathrm{day}^{-1}$ at surface level, declined sharply at increasing altitude and diminished at $4 \mathrm{~km}$. Above $4 \mathrm{~km}$ longwave radiation started to cool the atmosphere slightly reaching a maximum rate of $-0.1 \mathrm{~K} \mathrm{day}^{-1}$ at $6 \mathrm{~km}$.

\section{Introduction}

On Wednesday 26 March 2003, amidst the military Operation Iraqi Freedom, Kuwait and the surrounding northeastern region of the Arabian Peninsula was exposed to a dust storm. This dust storm that had already passed through Baghdad a day earlier (25 March) caused a slowdown in the advancement of US Army and hampered all military operations for the following $24 \mathrm{~h}$ (Atkinson, 2004). It was reported that the dust storm was so strong it blew over a 500 gallon fuel-tanker and injured one soldier. Dust and dust storms interfere with human life and function in various ways. They are known to cause health problems, especially to the respiratory system, leading to various forms of allergies (Wilson and Spengler, 1996; Griffin and Kellogg, 2004; Griffin, 2007; Achudume and Oladipo, 2009; Leski et al., 2011). Dust storms cause soil loss from dry lands and preferentially remove organic matter and the nutrient-rich lightest particles, thereby reducing agricultural productivity. Furthermore the abrasive effect of the dust storm damages young crop plants (Lyles, 1988; Simonson, 1995; Stefanski and Sivakumar, 2009; Ravi et al., 2010). The reduced visibility associated with all forms of dust phenomena impacts the local economy by affecting aircraft aviation and road transportation (De Villiers and Van Heerden, 2007). In certain occasions of severe dust storms it brings 
the whole locality to a stand still. However, dust can also have beneficial effects where it deposits. For example, Central and South American rainforests get most of their mineral nutrients from the Sahara dust fallout (Swap et al., 1992; Youlin et al., 2002); and the iron-poor ocean regions get their iron from the deposited dust (Carbo et al., 2005; Herut et al., 2005; Jickells et al., 2005; Mahowald et al., 2005).

Data retrieved by Total Ozone Mapping Spectrometer (TOMS) revealed the Arabian Peninsula as one of the major sources of dust emissions around the world after the African sources (Prospero et al., 2002; Washington et al., 2003; Goudie, 2009). The Mesopotamian source region identified by Wilkerson (1991) includes Syria, Iraq, western Iran and the northeastern Arabian Peninsula. Dust and dust storms initiated in areas lying between the Tigris and Euphrates rivers in southern Iraq, which expands over an area around $32^{\circ} \mathrm{N}, 32^{\circ} 17^{\prime} \mathrm{E}$, track their path southward over Kuwait and the southeastern parts of the Arabian Peninsula. Investigation of the physical and optical characteristics of dust aerosols is crucial to quantifying their radiative impact on the Earth radiation budget. Radiative forcing by dust particles can lead to either heating or cooling of the climate system depending on their single scattering albedo and the underlying surface albedo (Tegen and Lacis, 1996; Haywood and Boucher, 2000; IPCC, 2007). It can also strengthen the low-level frontogenesis leading to a significant intensification of dust storms (Chen et al., 1994). Furthermore, radiative forcing by dust particles modulate the low-level jet resulting in a diurnal variation of dust emission over arid and semi-arid regions (Alizadeh Choobari et al., 2013). A lot of ground-based and airborne measurement campaigns mainly in the African, Mediterranean and Asian regions have been conducted in recent years to analyze the optical and physical properties of dust aerosols (Sabbah et al., 2001; Ahn et al., 2007; Heinold et al., 2008; Kaskaoutis et al., 2008; McConnell et al., 2008; Osborne et al., 2008; Ansmann et al., 2011; Formenti et al., 2011; Haywood et al., 2011), the frequency of dust outbreaks (Goudie and Middleton, 1992; Gao et al., 2003; Kutiel and Fruman 2003, Rezazadeh et al., 2013) and their sources and transport range (Youlin et al., 2002; El-Askary et al., 2003, Washington et al., 2003; Xuana et al., 2004; Tsolmon et al., 2008; Rashki et al., 2012; Notaro et al., 2013). Several case studies of dust outbreaks have been conducted in which direct radiative forcing at the surface and at top of the atmosphere (TOA) have been calculated using ground-based and satellite-based data (Xu et al., 2003; Costa et al., 2006; Prasad et al., 2007; Di Sarra et al., 2008; Markowicz et al., 2008; Pandithurai et al., 2008; Di Biagio et al., 2010; Lemaître et al., 2010; Park et al., 2010; Sharma et al., 2012). The results are highly variable depending on their regional and temporal scales. The study of a severe dust storm taking place in the Arabian Peninsula in terms of its optical and physical characteristics and calculations of its radiative impact is quite scarce in literature. Therefore we present a case study of an intense dust storm that took place at a critical time of a major military operation. This paper is a continuum of the Saeed and Al-Dashti (2010) article, which examined the optical and physical properties of an intense dust storm that blew over Kuwait on 19 March 2003. The synoptic sequence leading to the dust storm is discussed in conjunction with local meteorological data. The instantaneous optical and physical properties of the dust aerosols that engulfed Kuwait during the 26 March 2003 dust storm and its subsidence over the following day, 27 March, are investigated from both ground-based data and satellite-based data and consequently source regions are identified. The atmospheric model SKIRON is employed to model the vertical profile of the dust column. Finally the Santa Barbara DISORT Atmospheric Radiative Transfer (SBDART) model is used to calculate atmospheric fluxes, radiative forcing and heating/cooling rates at TOA and surface levels at both shortwave and longwave bands of the electromagnetic spectrum.

\section{Study site}

Kuwait $\left(29^{\circ} 22^{\prime} \mathrm{N}, 48^{\circ} \mathrm{E}\right)$ is located at the northwestern tip of the Arabian (Persian) Gulf (Fig. 1). Kuwait is a small country that extends from $28^{\circ} 55^{\prime} \mathrm{N}$ to $30^{\circ} 1^{\prime} \mathrm{N}$ and $46^{\circ} 6^{\prime} \mathrm{E}$ to $48^{\circ} 4^{\prime}$ E. It lies between Saudi Arabia, Iraq, and the Arabian (Persian) Gulf. It has about $18000 \mathrm{~km}^{2}$ of sandy desert and coastal beaches with an estimated population of about two million. The climate of Kuwait and eastern Saudi Arabia is typical of an arid environment. It is characterized by long, hot, and dry summers; it also has short, warm, and sometimes rainy winters, with a mean of 4 inches of rain in Kuwait and 1 inch in coastal Saudi Arabia. The region is subject to violent storms during the spring and summer seasons. Dust storms are prevalent $5 \%$ of the time all throughout the year in Kuwait, but $3.5 \%$ of the daytime from March to August. During the spring season Kuwait is exposed to strong northwesterly shamal (meaning north in Arabic) winds that characterize the climate during the winter-spring seasonal transition. The shamal wind kicks up fine desert sand and silt along the Tigris and Euphrates river basins. The natural funneling of large air masses by high mountains in Turkey and Iran, combined with the high plateaus in Saudi Arabia, help to funnel air across the Mediterranean into the Arabian (Persian) Gulf (Perrone, 1979).

\section{Synoptic description}

The 26 March dust storm is a typical $24 \mathrm{~h}$ shamal dust storm that usually takes place at the spring-summer transition. The synoptic of this shamal dust storm is examined over the extended period of 23-28 March 2003. A low-pressure system moved eastward from western Libya on 23 March (Fig. 2a) into Egypt (Fig. 2b), with an approximate velocity of $17 \mathrm{~m} \mathrm{~s}^{-1}$. It stirred north African dust and sand and carried it aloft. This surface low was a reflection of an upper trough 

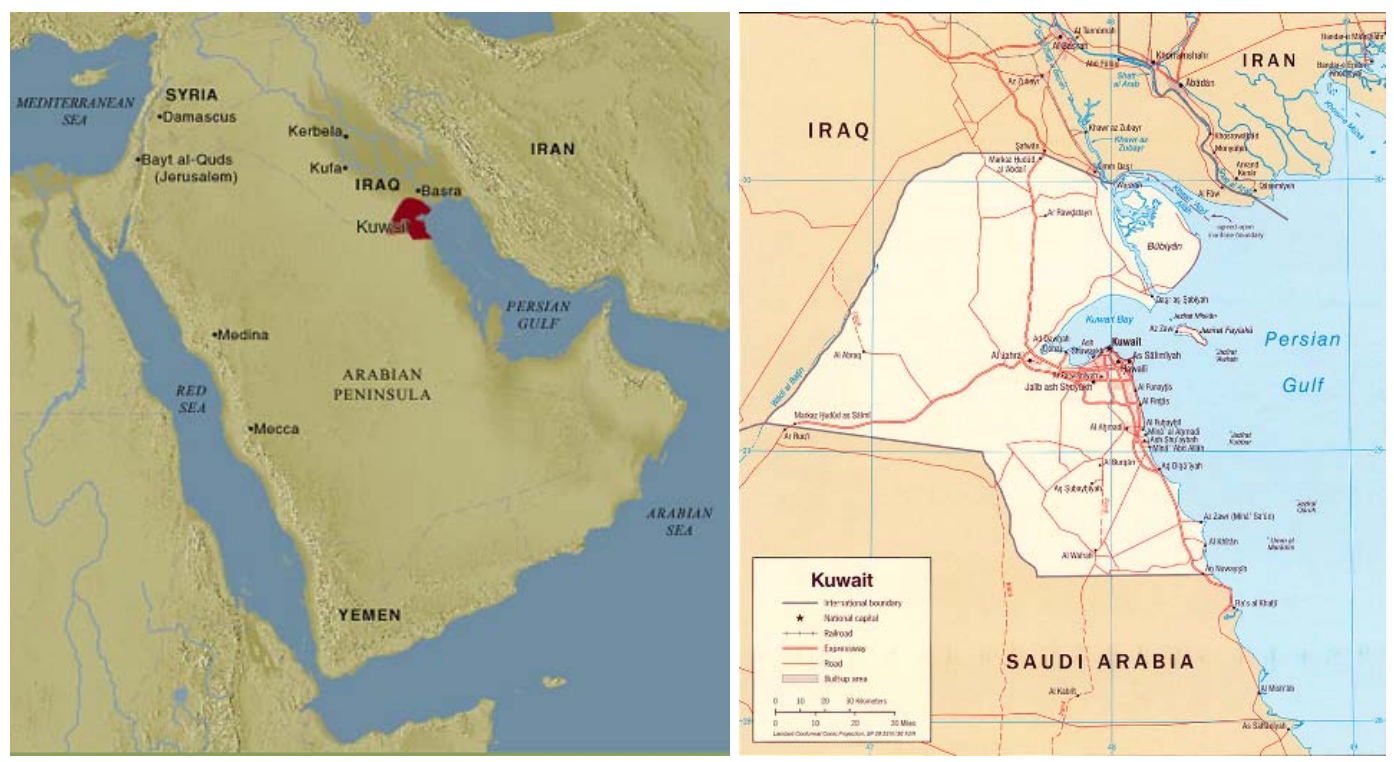

Fig. 1. Kuwait's geographical location within the Arabian Peninsula (red area, left panel), and an enlarged map of Kuwait (right panel).

centered over northern Turkey and the Black Sea (Fig. 3a), which then moved in the southeastern direction (Fig. 3b). By 25 March (Figs. 2c, 3c), the low-pressure system had stretched from north of the Mediterranean to its central parts. It resulted in a dust storm over Baghdad. The isotherms, superimposed over the contour lines, are also shown in Figs. 2 and 3. It is wave shaped with the ridge of the wave centered over the depression. This steep isothermal gradient moved along the depression over the whole period (23-28 March). A subtropical high pressure was generated behind the depression leading to cold air advection on the west side of the depression on 26 March. Meanwhile warm air advection was generated from the southwest towards the eastern side of the depression generating a baroclinic zone. This zone, where the contour lines intersect with the isotherms, continued its movement with the depression in its mature stage on 27 and 28 March. The warm advection caused south and southeasterly winds, known locally as Kaus to blow over Kuwait on 26 March. However the air stream set in west of the new surface low on 26 March created shamal winds reaching surface speeds of $11 \mathrm{~m} \mathrm{~s}^{-1}$ on 26 March (Fig. 4). The depression moved swiftly into Iran in the eastward direction by $27-$ 28 March (Fig. 2e, f). For the 500 hpa levels, Fig. 3d shows that the depression had weakened as it moved into the eastward direction. By 27-28 March, Fig. 3e and f, the depression had stalled over the northern Arabian Peninsula. The wind field relating to the 26 March dust storm over Kuwait is shown in Fig. 4. The isotachs are plotted at different geopotential heights. The plot shows an area of convergence taking place over central Saudi Arabia, the Arabian (Persian) Gulf and Iran. The cold shamal wind blowing from the Mediterranean was intersected with warm air stream blowing from southern Saudi Arabia resulting in a strong upward motion over Kuwait and southern Iraq. The dust storm thus generated on 26 March lasted for $7 \mathrm{~h}$ starting from 07:00 LT (local time) (+ 3 UTC; Coordinated Universal Time). The duration and severity of the dust storm over Kuwait was also exhibited in the horizontal distribution of the vertical motion $(\omega)$ at different geopotential heights (Fig. 5). The pressure gradient force was as steep as -0.25 at surface level and went up to -0.4 at $500-600 \mathrm{hpa}$. The severity of this dust storm and the high density of fine dust carried by the shamal and the wind from south of Saudi Arabia had caused a thick suspension of fine dust in the atmosphere that lasted for the following $24 \mathrm{~h}$ (27 March). The Kuwait Meteorology Department weather radar system, the METEOR 1600C, installed at Kuwait Airport, recorded the progress of the dust storm on 26 March 2003. Figure 6a shows the radar detection of the dust storm at its early stage, $\sim 07: 30$ LT. The $Z$ (reflectivity) display shows the dust engulfing Kuwait within the $60 \mathrm{~km}$ zone and extending to the north beyond the $120 \mathrm{~km}$ display range of the radar. By about 09:30 LT (Fig. 6b) the dust had covered most of Kuwait and extended easterly to the Gulf. The radial velocity scan recorded an average speed of $11-$ $12 \mathrm{~m} \mathrm{~s}^{-1}$ for the blowing dust storm from the northwestern direction.

\section{Ground-based versus satellite-based data and the identification of source regions}

\subsection{Ground-based measurements}

AOT measurements were acquired in Kuwait City. A fivechannel Microtops Sunphotometer (Solar Light Co.) was used to measure the daily AOT, $\tau_{\lambda}$, at five optical channels: 

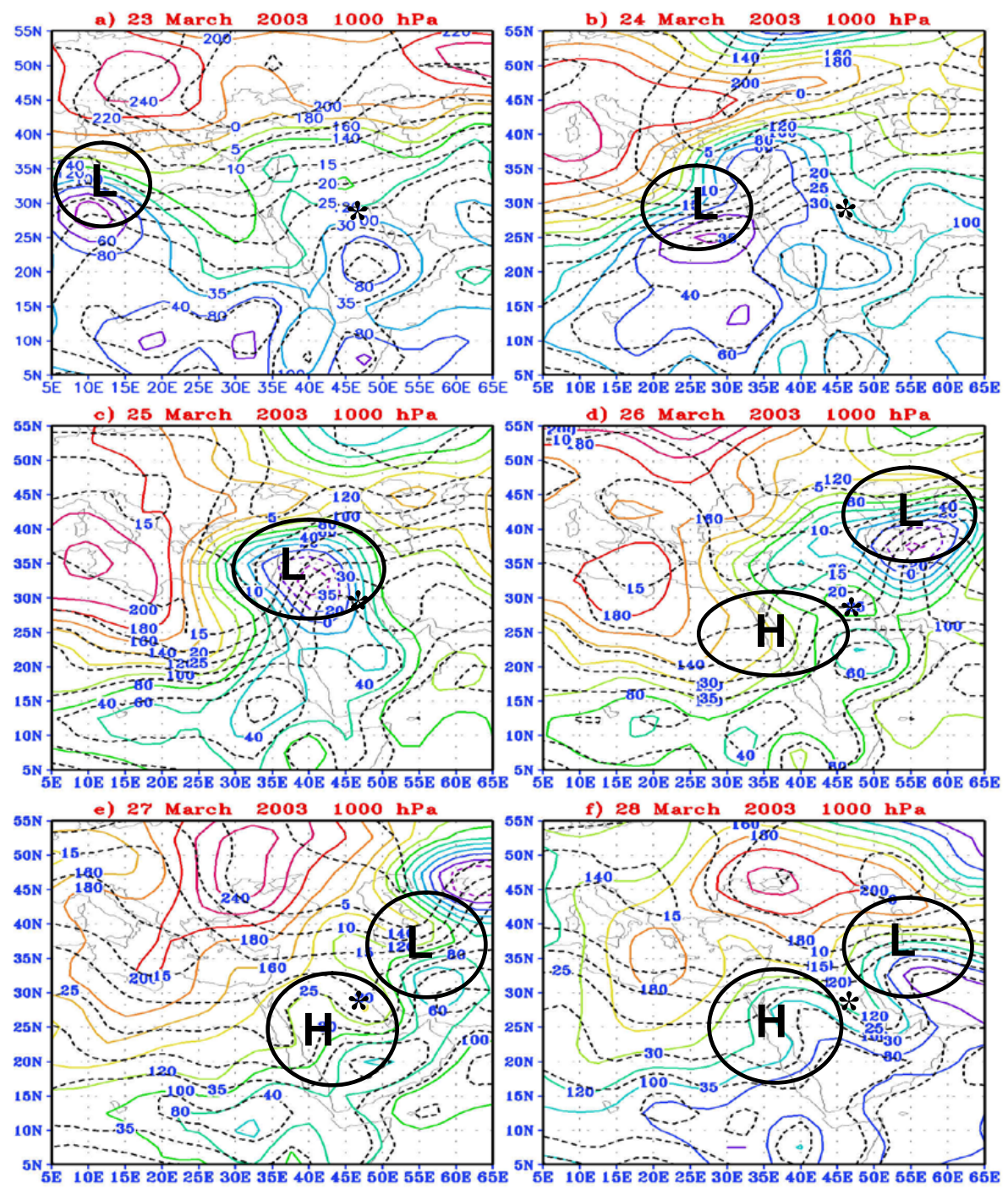

Fig. 2. Contour lines (solid lines) and isotherms (dotted lines) at $1000 \mathrm{mb}$ for the period of 23-28 March. The ellipses and circles show the low $(\mathrm{L})$ - and high $(\mathrm{H})$ - pressure zones. The star symbol $\left({ }^{*}\right)$ indicates the location of Kuwait.

$440,675,870,936$ and $1020 \mathrm{~nm}$. The water vapor (WV) column was also measured simultaneously in units of length using the channels 870,936 and $1020 \mathrm{~nm}$. The Ångstrom exponent $\alpha$ was derived using the 440 and the $870 \mathrm{~nm}$ channels according to the following equation (Stephens, 1994):

$\alpha_{870 / 440}=-\ln \left(\tau_{870} / \tau_{440}\right) / \ln (870 / 440)$.

The sunphotometer was calibrated by transferring calibration factors from a master sunphotometer. The master sunphotometer was calibrated using the method of Langley plot performed at the Mauna Loa observatory in Hawaii. The calibration was performed at the beginning of the measurement period. The absolute accuracy of measurements is expected to be \pm 0.02 for the optical thickness, with a precision four times better. AOT measurements at the five optical channels were highly correlated $(r=0.99)$. Therefore the AOT of the $675 \mathrm{~nm}$ channel, $\tau_{675}$, which is the most comparable to the mean dust particle size is used to represent the AOT. However, particulate matter concentrations of $10 \mu \mathrm{m}$ diameter or less, $\mathrm{PM}_{10}\left(\mu \mathrm{g} \mathrm{m}^{-3}\right)$, were acquired by the Environmental Protection Agency (EPA) station located in Jahra, $30 \mathrm{~km}$ west of Kuwait City. The station uses the BAM-1020 manufactured by Met One Instruments. The BAM-1020 (which stands for Beta Attenuation Mass Monitor) is one of several methods used to continuously monitor particulate matter. The air sampler uses a $10 \mu \mathrm{m}$ filter at the inlet pipe in order to restrict the particle size of the air sample to a maximum of $10 \mu \mathrm{m}$. The BAM-1020 works with a resolution of $\pm 2 \mu \mathrm{g} \mathrm{m}^{-3}$, and an accuracy of $\pm 8 \%$ of indication for $1 \mathrm{~h}$ operation mode, $\pm 2 \%$ compared to the Federal Reference Method for $24 \mathrm{~h}$ operation mode. A complete description of BAM-1020 operation is found at Gobeli et al. (2008). 

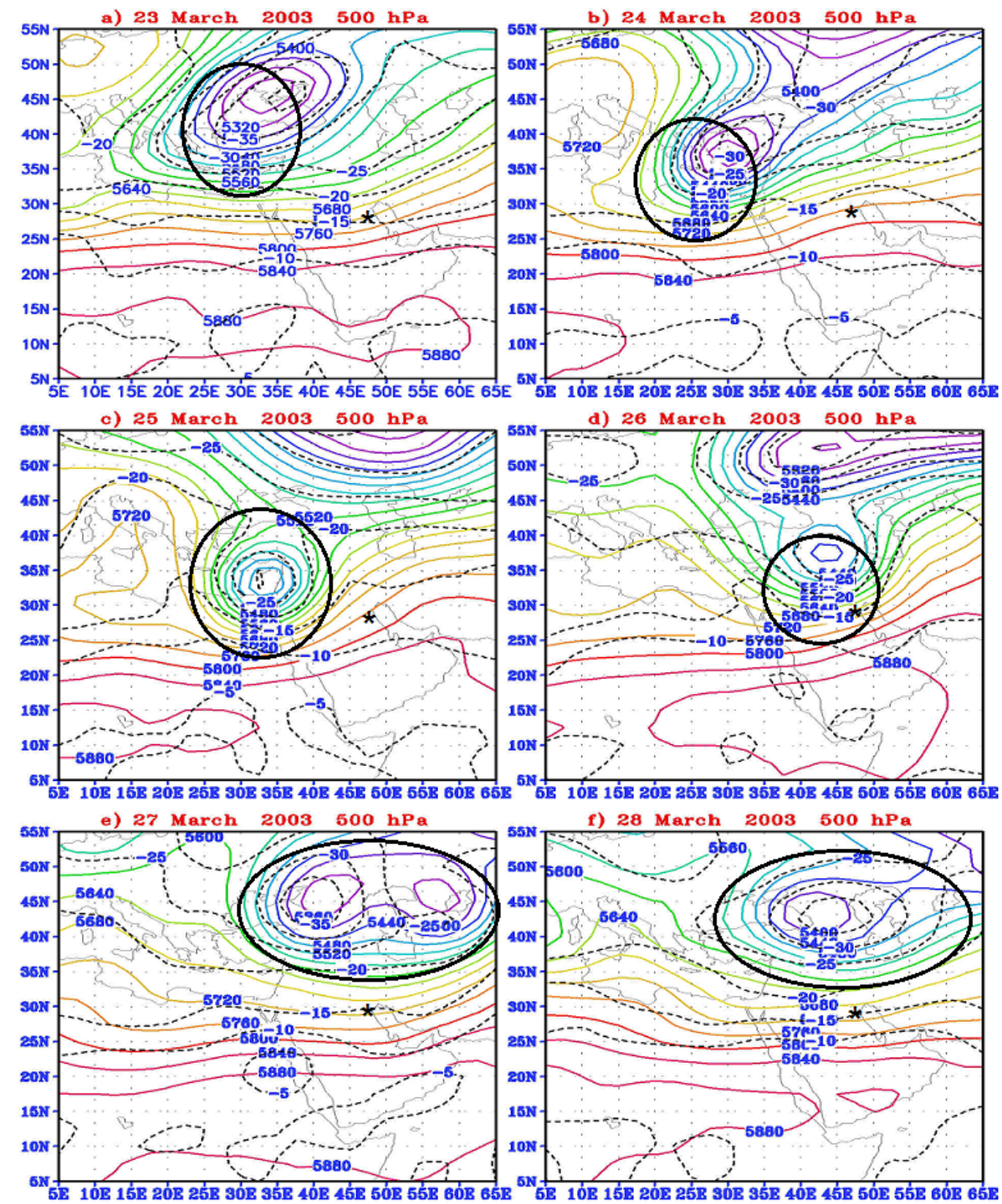

Fig. 3. Contour lines (solid lines) and isotherms (dotted lines) at $500 \mathrm{mb}$ for the period of 23-28 March 2003. The star symbol (*) indicates the location of Kuwait.

Finally, standard meteorological parameters were obtained from the Kuwait Meteorology Department, which are measured according to standard meteorological procedures approved by the World Meteorological Organization (WMO). The meteorological data were acquired on an hourly basis from a tower located at the vicinity of Kuwait International Airport, and rises $10 \mathrm{~m}$ a.g.l. (above ground level). The meteorological parameters used in this work are wind speed, WS $\left(\mathrm{m} \mathrm{s}^{-1}\right)$, wind direction, WD, horizontal visibility, HV $(\mathrm{km})$, expressed as the lowest horizontal visibility attained and weather phenomena (WP), which indicates the type of weather taking place at a certain time. There are a number of weather phenomena used by the Meteorological Department of Kuwait, which follows the definitions provided by the WMO (Aerodrome Reports and Forecast, 2005), among them are those associated with the dust phenomena. Dust storm (DS) is associated with strong wind exceeding $9 \mathrm{~m} \mathrm{~s}^{-1}$ and poor horizontal visibility of $1 \mathrm{~km}$ or less, whereas rising dust (RD) is associated with moderate wind speed ranging between 6 and $9 \mathrm{~m} \mathrm{~s}^{-1}$ and horizontal visibility between 1 and $5 \mathrm{~km}$. Suspended dust (S), however, arises when there is a thick suspension of dust in the lower troposphere in the absence of strong wind (WS $\leq 6 \mathrm{~m} \mathrm{~s}^{-1}$ ) whereby horizontal visibility might deteriorate to $1 \mathrm{~km}$ or less. Table 1 states the optical and physical measurements obtained on 2627 March at 11:30 LT together with the corresponding meteorological parameters. Since both AOT measurements are acquired at 11:30 LT, the physical and meteorological parameters were found as the average values of $\mathrm{PM}_{10}$, WS and $V$ between 11:00 and 12:00 LT. Aerosol optical thickness, $\tau_{675}$, 

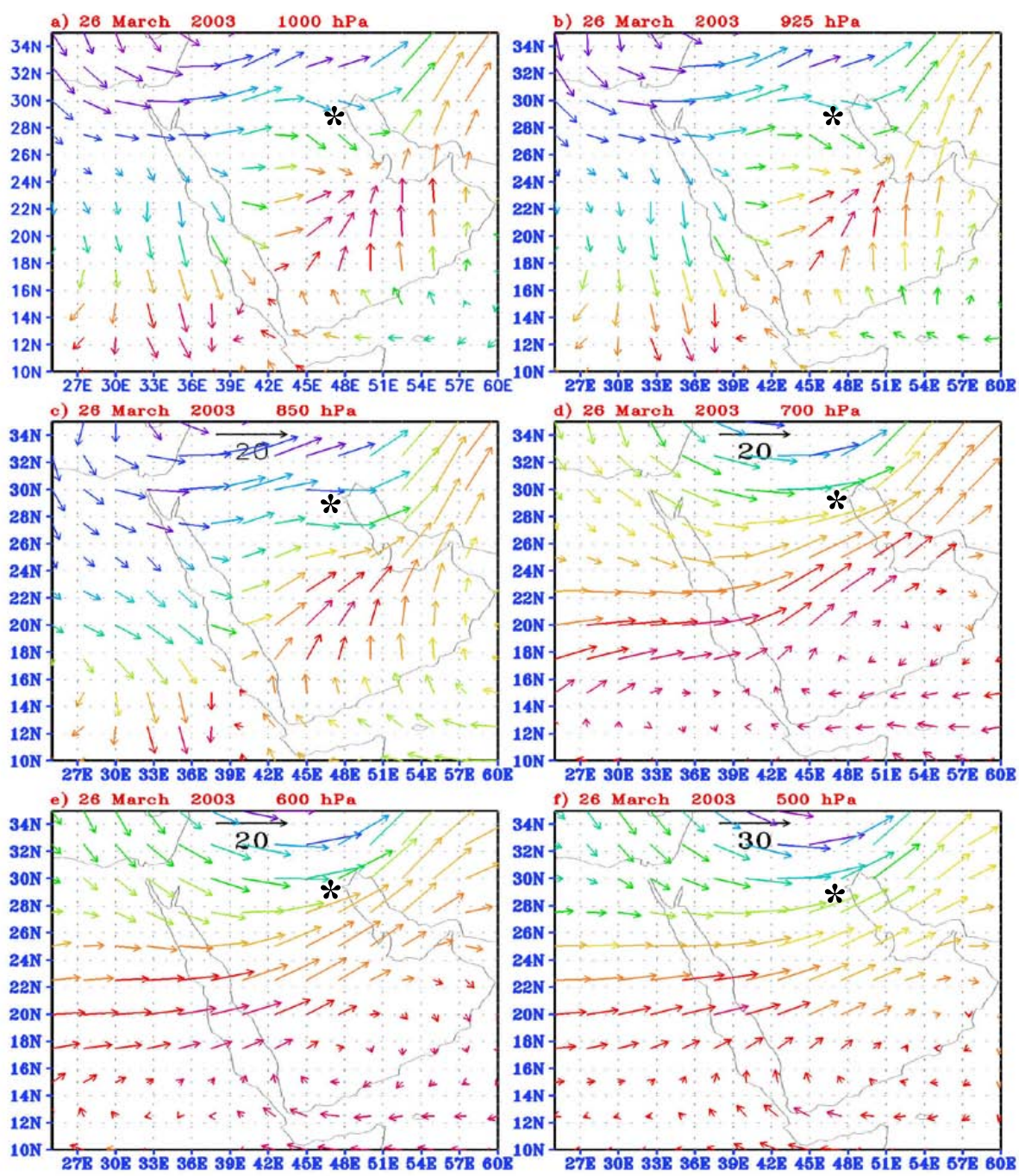

40

Fig. 4. Wind fields at different geopotential levels on 26 March 2003. The star symbol (*) indicates the location of Kuwait.

reached 3.617 on 26 March and 4.17 on 27 March whereas the Ångstrom coefficient, $\alpha_{870 / 440}$, dropped to -0.0234 and -0.0318 , respectively. The negative values of $\alpha_{870 / 440}$ reflects the dominance of coarse-sized dust particles. At the same time $\mathrm{PM}_{10}$ reached $1770 \mu \mathrm{g} \mathrm{m}^{-3}$ on 26 March and was increased to $2641 \mathrm{\mu g} \mathrm{m}^{-3}$ the following day at the time that AOT was measured. Figure 7 shows the hourly variations of meteorological parameters and $\mathrm{PM}_{10}$ concentrations on 2627 March. The strong southeasterly wind blew over Kuwait with a maximum wind speed of $14 \mathrm{~m} \mathrm{~s}^{-1}$ at 00:00 LT of 26 March. As the day broke out it changed direction to northwesterly shamal wind and continued to blow at an average speed of $10 \mathrm{~m} \mathrm{~s}^{-1}$ thus causing the dust storm. The blowing dust caused a severe reduction in visibility reaching a minimum of $200 \mathrm{~m}$ during dust storm hours but $400 \mathrm{~m}$ at the time AOT was measured. The associated suspended dust continued to hamper visibility all through the following day, 27 March, whereby visibility reached a minimum value of $300 \mathrm{~m}$ between 14:00 and 16:00 LT. By then the wind had lost its momentum and was blowing at a moderate speed of approximately $4 \mathrm{~m} \mathrm{~s}^{-1}$ from the north and northwestern directions. The $\mathrm{PM}_{10}$ measurement of dust concentration peaked at $4800 \mathrm{\mu g} \mathrm{m}^{-3}$ during dust storm hours on 26 March, and fluctuated with an average value of $1000 \mu \mathrm{g} \mathrm{m}^{-3}$ throughout the following day before the visibility improved after 16:00 LT on 27 March. The relative humidity increased when the wind was southeasterly and decreased when the wind was northerly to northwesterly. 

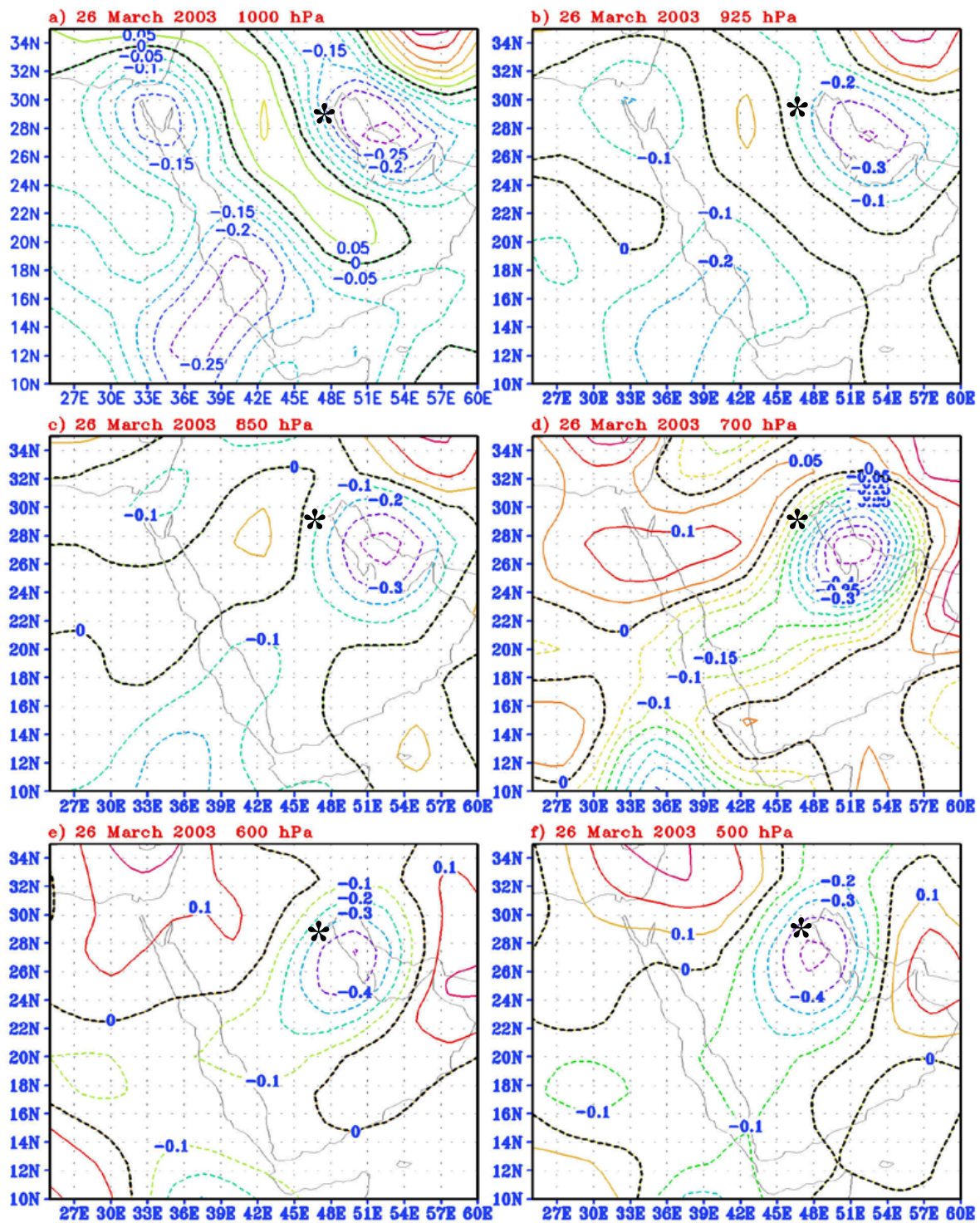

Fig. 5. Horizontal distribution of the vertical motion $(\omega)$ at different geopotential heights on 26 March. The star symbol $\left(^{*}\right)$ indicates the location of Kuwait.

Table 1. The dust storm's optical and physical properties together with the average $\mathrm{PM}_{10}$ and the corresponding meteorological parameters at 11:30 LT (+3 UTC).

\begin{tabular}{lll}
\hline & 26 March & 27 March \\
\hline$\tau_{675}$ & 3.617 & 4.17 \\
$\alpha_{870 / 440}$ & -0.0234 & -0.0318 \\
$\mathrm{PM}_{10}\left(\mu \mathrm{g} \mathrm{m}^{-3}\right)$ & 1770 & 2641 \\
\left.${\mathrm{WS}\left(\mathrm{m} \mathrm{s}^{-1}\right)}\right)$ & 10.5 & 4.5 \\
$\mathrm{HV}(\mathrm{km})$ & 0.4 & 1.25 \\
WD & NW & SW, W \\
WP & DS & S
\end{tabular}

\subsection{Satellite-retrieved data and identification of source regions}

Moderate Resolution Imaging Spectroradiometer (MODIS)retrieved AOD by the Deep Blue algorithm is presented here to complement the limited ground-based optical measurements. MODIS sensors on board earth orbiting systems Aqua (local Equator crossing time 13:30) and Terra (local Equator crossing time 10:30) are polar-orbiting sun-synchronized satellites. They are flown at an altitude of $705 \mathrm{~km}$ and have a wide swath of $2330 \mathrm{~km}$ to ensure a daily coverage of the globe. They retrieve spectral information in 36 different spectral bands ranging from 0.414 to $14.235 \mu \mathrm{m}$ of which several bands fall in the visual and near-infrared bands $(0.47$ $2.1 \mu \mathrm{m}$ ) that are suited for aerosol retrievals (Tanré et al., 


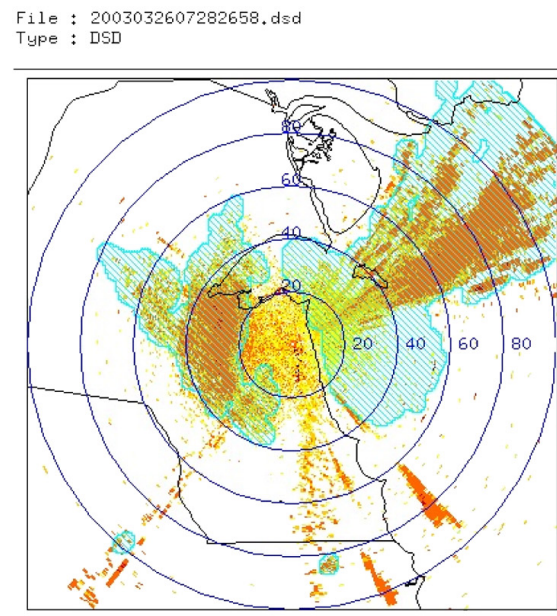

(a)
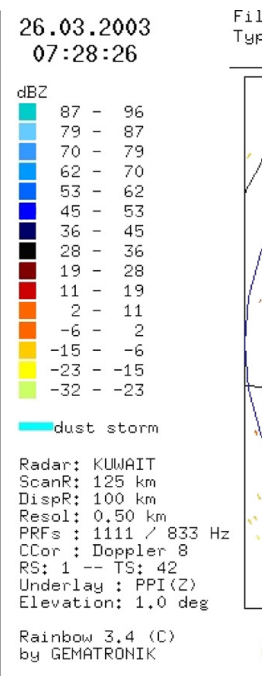

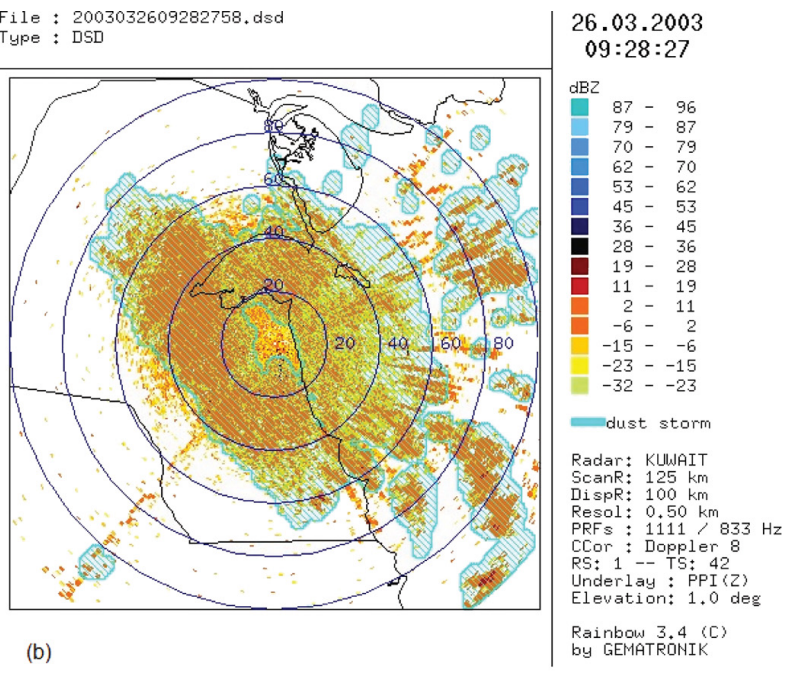

(b)

Fig. 6. The radar display of reflectivity $Z$ at the beginning of the dust storm, approximately 07:30 LT (a), and at a later stage, approximately 09:30 LT (b).

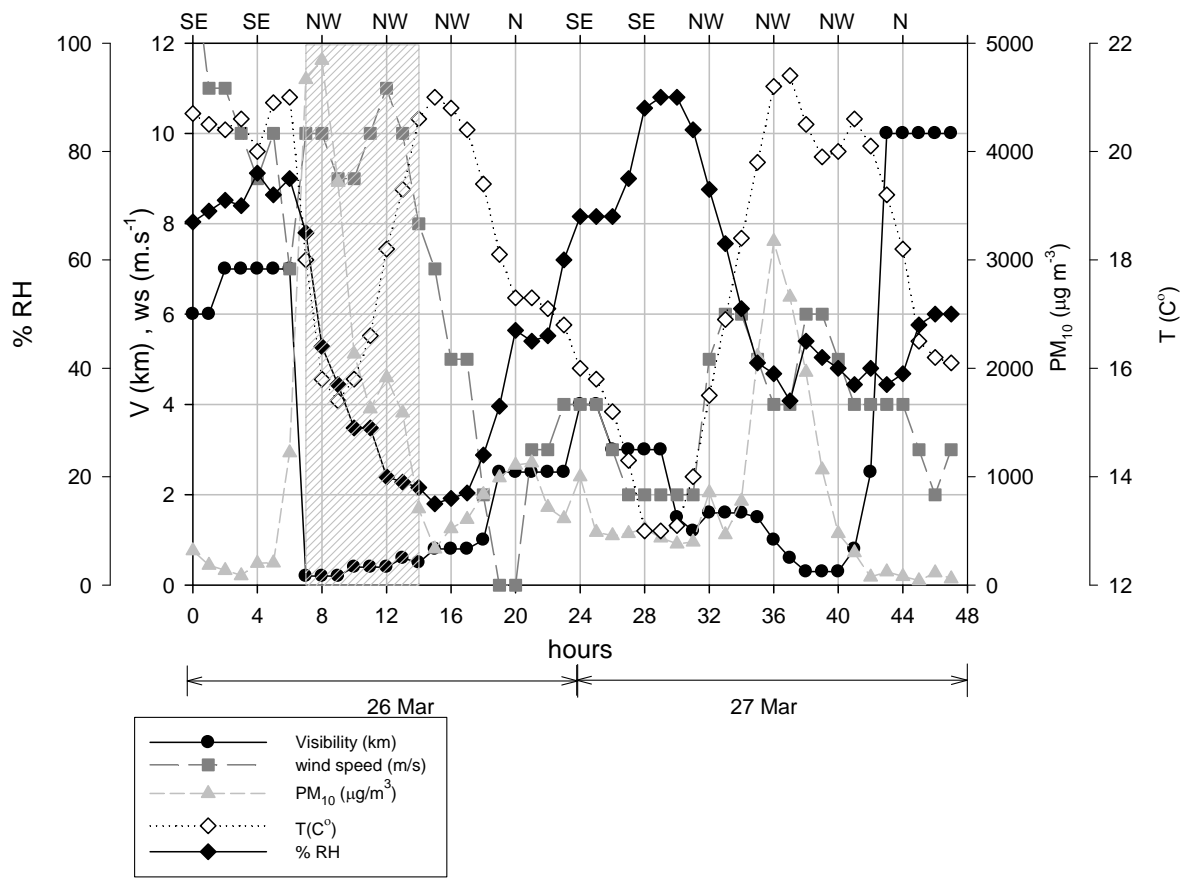

Fig. 7. Hourly variation of visibility, $V(\mathrm{~km})$, wind speed, WS $\left(\mathrm{m} \mathrm{s}^{-1}\right), \mathrm{PM}_{10}\left(\mu \mathrm{g} \mathrm{m}{ }^{-3}\right)$, temperature $\mathrm{T}\left({ }^{\circ} \mathrm{C}\right)$ and wind direction (top axis) for 26-27 March 2003. The shaded area represents dust storm hours at Kuwait local time (+ 3 UTC).

1997; Kaufman et al., 1997; King et al., 1999). Aerosol optical depth at various optical wavelengths is retrieved from measured radiances and processed through the application of various algorithms. The AOD products have been validated extensively throughout the literature mainly by comparisons with the ground-based AErosol Robotic NETwork (AERONET) observations (Ichoku et al., 2002, 2005; Remer et al., 2005, 2008; Levy et al., 2005, 2010). The Deep Blue algorithm is an algorithm developed to overcome the problems associated with aerosol retrievals over bright-reflecting surfaces such as deserts and semiarid regions (Hsu et al., 2004, 2006). It basically employs radiances from the blue channels, where surface reflectance over land is much lower than that for longer wavelength channels, to infer the properties of aerosol over bright surfaces. The RGB (red, green, blue) image captured by the Terra-MODIS satellite (Fig. 8a), 

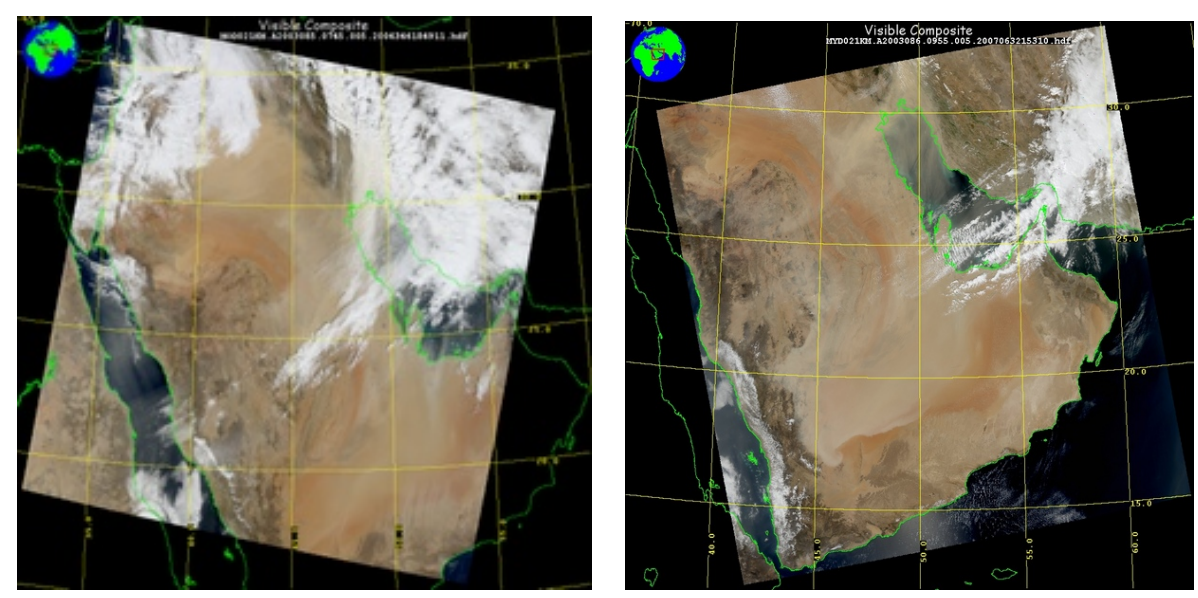

Fig. 8. Terra-MODIS RGB image captured on 26 March shows the dust front moving from the northwesterly direction into Kuwait (a). The 27 March rising dust captured by Aqua MODIS shows clearly a thin layer of dust covering most of the Arabian (Persian) Gulf (b).

depicts clearly the intensity of the dust storm that engulfed the eastern side of the Arabian Peninsula on 26 March, whereas its aftermath is shown as a thin layer of dust over the Arabian (Persian) Gulf (Fig. 8b). AOD at the $550 \mathrm{~nm}$ channel, $\mathrm{AOD}_{550}$, was retrieved by the MODIS Deep Blue algorithm, collection 5 level 3 quality controlled land only from both Terra and Aqua platforms. Table 2 presents the $\mathrm{AOD}_{550}$ data averaged over the Kuwait area. Both sensors retrieved elevated values of AOD with the Aqua MODIS sensor retrieving a slightly higher AOD than Terra MODIS. This is due to the different times that Terra and Aqua platforms passed over Kuwait and hence the different scenes that went into making the final product. Latitude-longitude maps of $\mathrm{AOD}_{550}$ field over the Arabian Peninsula (Fig. 9a-d) reveal high AOD mostly concentrated along the eastern coast of the Arabian (Persian) Gulf. The TOMS-derived aerosol index (AI) is another indicator of dust loading in the atmospheric column (Torres et al., 1998), which has been used extensively to identify source regions of dust around the globe (Goudie and Middleton, 2001, 2006; Prospero et al., 2002; Ginoux and Torres, 2003; Giles, 2005). TOMS AI for both days of interest is shown in Table 2 . The slightly higher AI on 27 March is caused by the elevation of fine dust particles to the boundary layer. Furthermore, the TOMS-retrieved AI field over the Arabian Peninsula (Fig. 9e, f) shows two regions of high dust activity or "hot spots" with an AI of around 3. One of them is located around Kuwait and the southern parts of Iraq and the other one is located around the central southeastern parts of the Arabian Peninsula. As the dust storm stalled on 27 March the fine dust particles were elevated to the boundary layer, which caused the AI to exceed 4.5 (Fig. 9f). The northern hot spot is located in Kuwait within the vicinity of the lower Mesopotamian source region, which extends from $44^{\circ} 57^{\prime}-46^{\circ} 17^{\prime} \mathrm{E}$ and $31^{\circ}-32^{\circ} \mathrm{N}$ (Wilkerson, 1991). Middleton (1986) had demonstrated that this source region has the highest number of dust storms per year
Table 2. MODIS Deep Blue $\mathrm{AOD}_{550}$ obtained over the Kuwait area (latitude 28.745-29.997 and longitude 46.8-47.7).

\begin{tabular}{|c|c|c|c|c|}
\hline & \multicolumn{2}{|c|}{26 March } & \multicolumn{2}{|c|}{27 March } \\
\hline & Terra & Aqua & Terra & Aqua \\
\hline $\mathrm{AOD}_{550}$ & $0.85 \pm 0.166$ & $1.136 \pm 0.31$ & $1.042 \pm 0.248$ & $1.204 \pm 0.35$ \\
\hline TOMS AI & \multicolumn{2}{|c|}{$2.95 \pm 0.66$} & \multicolumn{2}{|c|}{$3.77 \pm 0.93$} \\
\hline
\end{tabular}

compared to other source regions in the Middle East. The southern hot spot is the Rub'al Khali (or the Empty Quarter) source region, which extends across the middle-southeastern parts of the Arabian Peninsula covering an approximate area of $650000 \mathrm{~km}^{2}$ (Fig. 10). This vast land of prolific sand is considered as one of the five major sources of dust coming after the Bodélé Depression of the south-central Sahara and the western Sahara region of Mali and Mauritania with a maximum mean aerosol index above 2.1 (Washington et al., 2003). These results are in total agreement with the results of a recent study conducted by Notaro et al. (2013), who analyzed air parcel trajectories over Saudi Arabia and remotely sensed AOD associated with dust outbreaks. They identified the Rub'al Khali region to be the prime source of dust for the central and eastern parts of the Arabian Peninsula in addition to the Iraqi desert for the north and northeastern parts of the Arabian Peninsula. Furthermore, Ginoux et al. (2012) investigated source regions of dust with the distinction between natural and anthropogenic sources. They identified three main source regions: the Mesopotamian region, which encapsulates most of Iraq, the central to eastern region of Saudi Arabia and the Rub'al Khali region. For this specific dust storm under consideration it thus becomes apparent that the dust transport over Kuwait came from the lower Mesopotamian and the Rub'al Khali regions. 


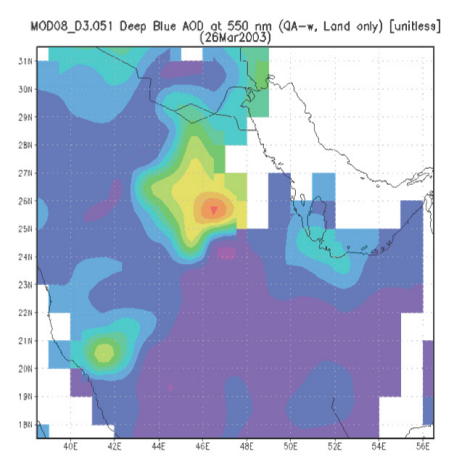

(a)

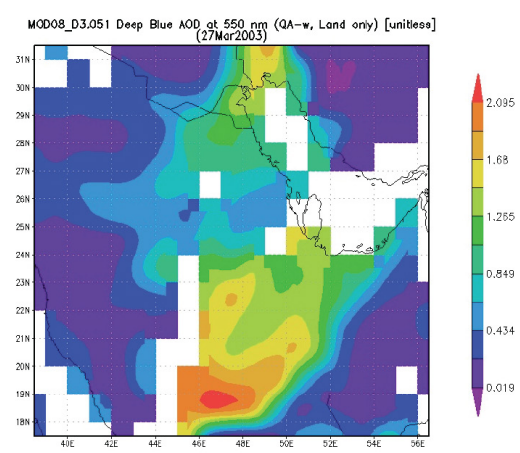

(c)

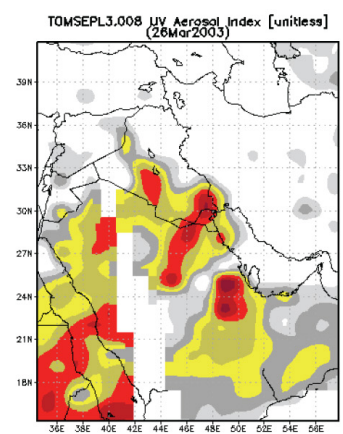

(e)

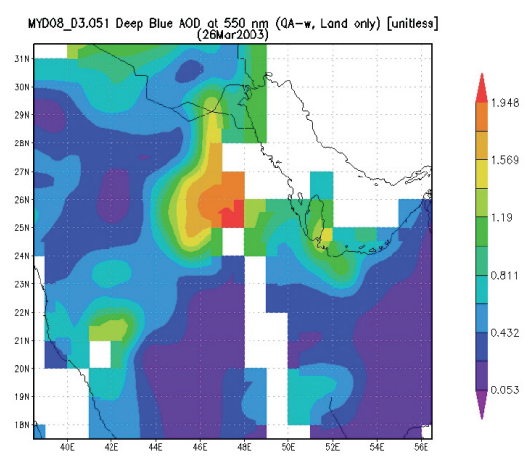

(b)

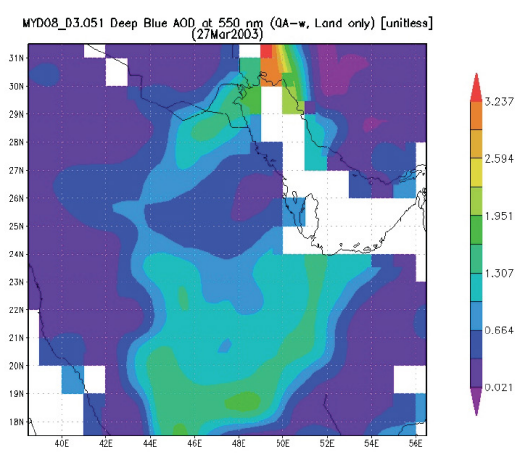

(d)

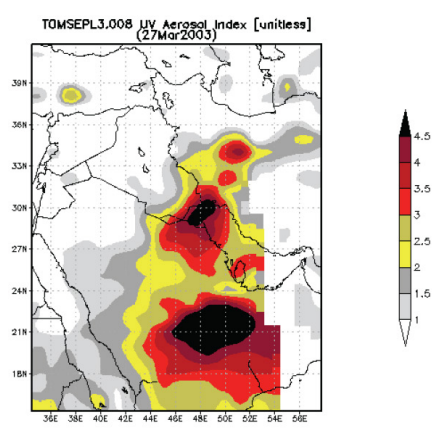

(f)

Fig. 9. MODIS Deep Blue algorithm retrieval of $\mathrm{AOD}_{550}$ over the Arabian Peninsula on 26 March for Terra satellite (a), Aqua satellite (b), and on 27 March for Terra satellite (c), Aqua satellite (d). TOMS AI field distribution across the Arabian Peninsula for the 26 March dust storm (e) and 27 March (f).

\section{Vertical distribution of the dust layer}

The vertical profile of the variation of desert dust concentration with height is important in implementing various radiative transfer models and in the evaluation of radiative forcing and heating rates. According to Liao and Seinfeld (1998), under cloud-free conditions, the shortwave radiative forcing at surface level and TOA is not sensitive to the altitude of the dust layer but depends primarily on the reflectivity of the underlying surface, aerosol's optical thickness and aerosol's single scattering albedo. However the altitude of the dust layer influences the longwave radiative forcing. As the dust layer increases in height its overall temperature decreases and therefore reduces longwave radiative forcing at both TOA and surface level. In the absence of 


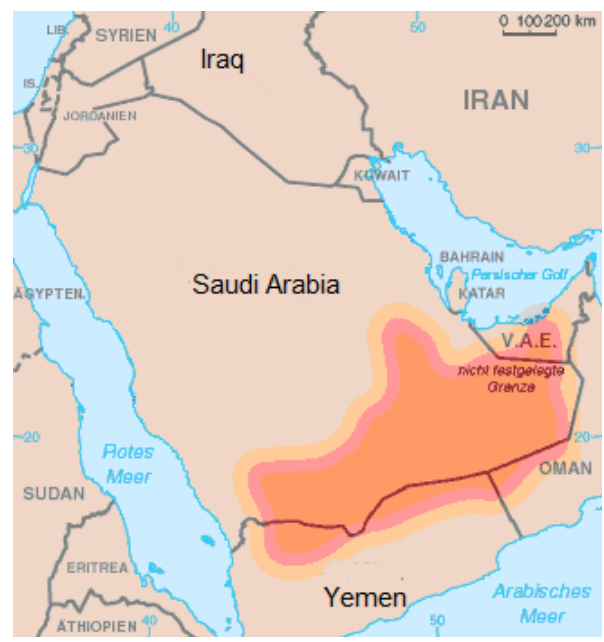

Fig. 10. Rub'al Khali (colored red) is one of the most prolific dustproducing regions of the globe. It dominates the southern parts of the Arabian Peninsula.

in situ measurements of the vertical distribution of the dust layer, the SKIRON atmospheric model is used to simulate the desert dust vertical profile.

\subsection{Model description}

SKIRON is an atmospheric model developed at the University of Athens by the Atmospheric Modeling and Weather Forecasting Group (Kallos et al., 1997, 2006) in the framework of the nationally and European Union (EU) funded projects SKIRON, Mediterranean Dust Experiment (MEDUSE), Atmospheric Deposition and Impact on the Open Mediterranean Sea (ADIOS), and recently Climate Change and Impact Research (CIRCE) and Marine Renewable Integrated Application Platform (MARINA). The atmospheric model is based on the ETA/NCEP (National Centers for Environmental Prediction) model, which was originally developed by Mesinger (1984) and Janjic (1984) at the University of Belgrade, but is heavily modified to include state-of-the-art parameterization schemes for meteorological and desert dust processes (Spyrou et al., 2010). The model includes a 16-category soil characteristics data set (Miller and White, 1998) that provides detailed information of the soil's physical properties, such as porosity and available water capacity. A high-resolution ( $30 \mathrm{~s})$ global land use and cover database is used, which includes urban areas that are classified according to the United States Geological Survey (USGS) into a 24-category land use/land cover system (Anderson et al., 1976). SKIRON incorporates a modal representation to describe the distribution of the aerosol mass over source areas. According to this method, the mass distribution is provided by the three-modal lognormal function of D'Almeida (1987), as described in detail by Zender et al. (2003). Dust production is initiated by the entrainment of large sand-sized particles $(\sim 60 \mu \mathrm{m}$ in diameter) through the process of saltation bombardment (Zender et al., 2003). Clay and silt sized particles are produced when the latter ones impact on the soil downwind of their saltation trajectories (Gillette, 1977). These particles with radius $r \leq 10 \mu \mathrm{m}$ stay in the atmosphere long enough to be transported over large distances (Zender et al., 2003; Spyrou et al., 2010). The dust particle size distribution follows a lognormal distribution with mass median diameter equal to $2.524 \mu \mathrm{m}$ and a geometric standard deviation of 2 . The transport mode uses eight size bins with effective radiuses of $0.15,0.25,0.45,0.78$, $1.3,2.2,3.8$, and $7.1 \mu \mathrm{m}$, similar to the size bins selected by Pérez et al. (2006). The dust particles that are mobilized through the process of saltation bombardment are deposited via dry (diffusion, impaction, gravitational settling) and wet (in-cloud and below-cloud removal) mechanisms. More details on the specific characteristics of the atmospheric model and dust module are provided in Spyrou et al. (2010).

\subsection{SKIRON simulation of the dust vertical profile}

In order to generate the vertical profile of dust over our period of interest SKIRON was run over the geographical area extending from $67.2^{\circ}$ to $21.3^{\circ} \mathrm{E}$ and $7.6^{\circ}$ to $44.2^{\circ} \mathrm{N}$, which covers the Arabian Peninsula, parts of eastern Africa and western Asia for the time period of 25-29 March 2003. The vertical profile of dust concentration was generated by integrating over the designated area from the surface or nearsurface level up to $20 \mathrm{~km}$ a.s.l. (above sea level) in $38 \mathrm{lev}$ els with a horizontal resolution of $0.2^{\circ} \times 0.2^{\circ}$. The ECMWF (European Centre for Medium-Range Weather Forecasts) reanalysis fields were used to set the initial boundary conditions with a spatial resolution of $0.5^{\circ} \times 0.5^{\circ}$. The lateral boundary conditions were updated every $3 \mathrm{~h}$. The spin-up time for the model was 20 days in order to adequately account for the background dust loading. Figure 11 shows an example of the dust concentration profile over the region of interest generated for 26 March at two levels; near ground level (Fig. 11a) and at an elevation of $1570 \mathrm{~m}$ from ground level (Fig. 11b). The aerial, integrated vertical distribution of dust concentration for the period of 25-29 March 2003 is shown in Fig. 12. The severity of the 26 March dust storm is clearly shown in Fig. 12 with two pockets of high dust concentration exceeding $1000 \mu \mathrm{g} \mathrm{m}^{-3}$ and extending slightly above $2 \mathrm{~km}$ from surface level. The medium-sized particles are elevated to approximately $3 \mathrm{~km}$ a.s.l. and the finest dust particles are raised up to $6 \mathrm{~km}$ from the surface level. A similar profile was obtained by Alpert et al. (2004), who investigated the vertical profile of the Saharan dust at its source and as it gets transported to the eastern Mediterranean island of Lampedusa and Sede Boker in Israel. Sede Boker, being located at the northwestern side of the Arabian Peninsula, has similar climatological conditions to Kuwait and therefore the spring season witnesses the highest rate of blowing dust. They found that the desert dust was elevated 

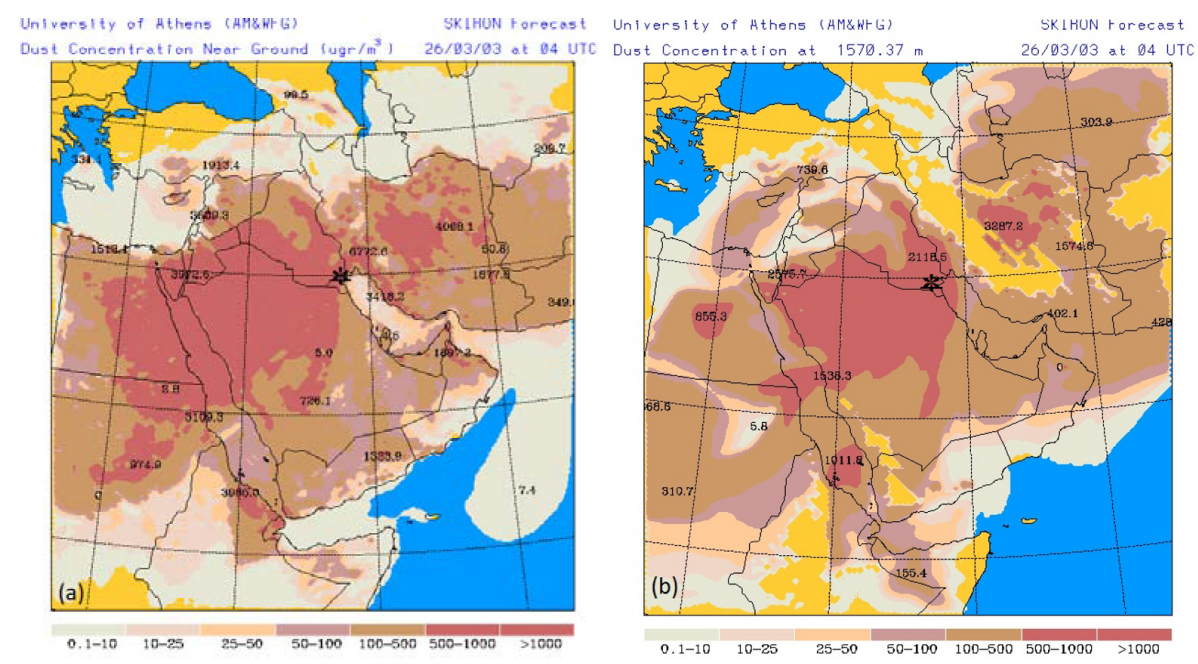

Fig. 11. Dust concentration $\left(\mu \mathrm{m}^{-3}\right)$ on 26 March for near-ground level (a), and at an elevation of $1570 \mathrm{~m}$ from ground level (b). The * indicates Kuwait's location.

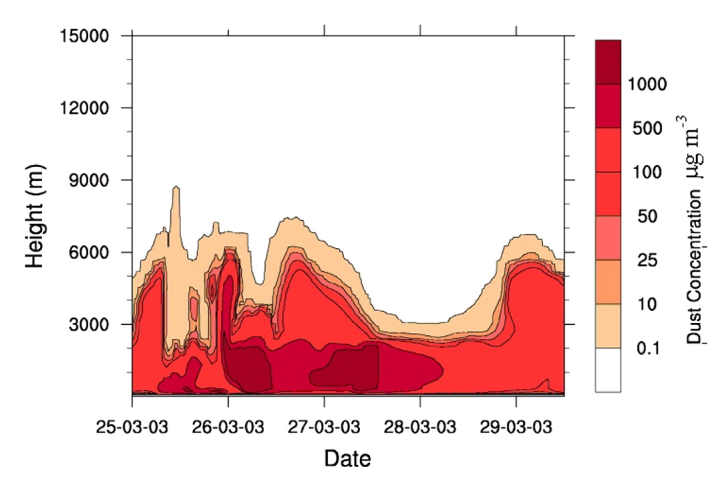

Fig. 12. The SKIRON atmospheric modeling of the dust's aerial, integrated vertical profile for the period of 25-29 March 2003. Two pockets of high dust concentration are generated around 2627 March.

to approximately $4-6 \mathrm{~km}$ above ground. Abdi Vishkaee et al. (2011) studied dust transport from the Syrian and Iraqi deserts into the northwestern region of Iran using groundbased lidar measurements. They investigated the dust layer thickness and height through two dust emission cases, which were in response to strong shamal winds. For the first case, which took place in August 2007, the dust layer of a thickness of $2 \mathrm{~km}$ and less was carried above a clean layer at a height of $3.5 \mathrm{~km}$. For the second case of dust emission, which took place in September 2008, the dust layer which had a thickness of $1-1.5 \mathrm{~km}$ was carried at a level below $3.5 \mathrm{~km}$.

\section{Direct radiative forcing}

\subsection{Model description}

Shortwave (SW; 0.28-3.42 $\mu \mathrm{m}$ ), longwave (LW; 3.42$500 \mu \mathrm{m})$ and net radiative flux from surface level up to the TOA were calculated, in units of watts per square meter, using the atmospheric radiative transfer model SBDART (Ricchiazzi et al., 1998). The model is based on a number of wellestablished radiative transfer models such as Discrete Ordinates Radiative Transfer (DISORT) (Stamnes et al., 1988), LOWTRAN (Kneizys et al., 1983) and MODTRAN (Berk et al., 1989), which were developed by various atmospheric research groups. The direct radiative forcing (DRF) at a certain level is defined as the difference in net flux, flux $x_{\circ}$, between the dust laden, flux $_{\circ, \mathrm{a}}$, and dust free, $f_{\text {flux }}$,cl, atmosphere at the specific level for SW or LW bands of the spectra. Therefore DRF at TOA or surface (surf) levels, DRF $F_{\mathrm{TOA} / \text { surf }}$, is

$$
\mathrm{DRF}_{\mathrm{TOA} / \text { surf }}=\left(\text { flux }_{\circ, \mathrm{AOT} / \mathrm{surf}}\right)_{\mathrm{a}}-\left(\text { flux }_{\circ, \mathrm{AOT} / \mathrm{surf}}\right)_{\mathrm{cl}} \text {. }
$$

Net fluxes at either TOA or surface level, flux ${ }_{\mathrm{O}_{\mathrm{AOT}} / \mathrm{surf}}$, for $\mathrm{SW}$ or LW bands of the spectra were computed as the difference between the net downwelling flux, flux $\downarrow$, and the net upwelling flux, flux。 $\uparrow$.

flux $_{\circ, \mathrm{AOT} / \mathrm{surf}}=$ flux $_{\circ} \downarrow-$ flux $_{\circ} \uparrow$

The SBDART model calculates radiative flux at certain level based on the aerosol's physical and optical properties, surface characteristics, atmospheric characteristics and the solar geometry of the geographic location. Among all these variables the most crucial is the surface reflectivity (or albedo), $R_{\mathrm{s}}$, AOT $\tau_{\lambda}$, aerosol single scattering albedo $\omega_{\circ}$ and the asymmetry parameter $g$. The surface albedo is defined as the ratio between reflected radiation and incident radiation. 
Highly reflective surfaces such as snow have their surface albedo close to 1 whereas dark surfaces such as forests and oceans have low surface albedo close to zero. The aerosol's single scattering albedo is defined as the ratio between the aerosol's scattering coefficient to the aerosol's total extinction coefficient. For high scattering aerosols such as mineral dust $\omega_{\circ}$ would be close to 1 , usually around 0.89 , and for low scattering aerosols $\omega_{\circ}$ would be around 0.76 . Low $\omega_{\circ}$ arises when aerosols absorption increases, a case usually associated with the presence of atmospheric pollutants such as black carbon. The aerosol asymmetry parameter $g$, which is a parameter representing the aerosol's phase function is more complex in its evaluation as it cannot be measured directly like the former variables. The parameter $g$ represents the average cosine of the scattered radiation angle. It is proportional to the aerosol size; larger particles tend to have larger $g$. The asymmetry parameter can have values between 0 and 1 where 0 represents isotropic scattering and 1 represents total forward scattering. However, most common values of $g$ fall between 0.6 and 0.88. Liao and Seinfeld (1998) had investigated the impact of some of these variables on the net radiative forcing (RF) at both surface level and TOA. They found that under clear sky conditions the SW forcing at either level decreases as surface albedo increases by a factor of $\left(1-R_{\mathrm{S}}\right)$ whereas LW radiative forcing is not sensitive to surface albedo and remains always positive at both levels. However, SW RF has a strong dependence on AOT. Cooling of the TOA and surface level increases linearly as AOT increases. In contrast, LW RF is less sensitive to AOT, it increases only slightly with the increase in AOT. The RF dependence on single scattering albedo is more complex because it depends on the change in planetary albedo, which could vary due to the addition of a thin layer of aerosols. There exists a critical single-scattering albedo, $\omega_{\mathrm{cr}}$, above which cooling takes place and below which heating takes place. The $\omega_{\mathrm{cr}}$ is given by Chylek and Coakley (1974) and Seinfeld and Pandis (1998) as

$\omega_{\mathrm{cr}}=\frac{2 R_{\mathrm{s}}}{2 R_{\mathrm{s}}+\beta\left(1-R_{\mathrm{S}}\right)^{2}}$,

where $\beta$ is the aerosol's upscatter fraction. It has been shown that $10 \%$ of overestimation of $g$ can result in about $12 \%$ reduction in RF (Marshal et al., 1995).

\subsection{Input parameters}

Here due to the limitation of our in situ measurements to only AOT, we have taken the approach of assigning realistic values to some of these variables. Table 3 lists the input parameters of the SBDART model that were either measured or estimated. The AOT has been measured and discussed and the associated cosine of the solar zenith angle (CSZA) is stated. The single scattering albedo, $\omega_{0}$, was assigned a high value of 0.98 based on recent measurements of scattering and absorption coefficients conducted by the
Table 3. The critical input parameters of the SBDART model.

\begin{tabular}{lll}
\hline & 26 March & 27 March \\
\hline$\lambda(\mu \mathrm{m})$ & 0.675 & 0.675 \\
$\tau_{\lambda}$ & 3.617 & 4.17 \\
$\omega$. & 0.984 & 0.984 \\
$g$ & 0.73 & 0.73 \\
$\mathrm{HV}(\mathrm{km})$ & 0.4 & 1.25 \\
$\mathrm{RH}$ & 0.25 & 0.39 \\
CSZA & 0.88 & 0.88 \\
\hline
\end{tabular}

first author in Kuwait City under similar atmospheric conditions of high dust loading and elevated AOT. The scattering coefficient was measured using an integrated nephelometer and absorption coefficient was measured using a multiangle absorption photometer. Moreover, similar high values of single scattering albedo has also been reported in literature under high dust loading ( $\mathrm{Li}$ et al., 2004; Mallet et al., 2009; Prasad et al., 2007; Markowicz et al., 2008). The asymmetry parameter $g$ is assigned a standard value of 0.73 , which is most commonly used for mineral dust (Sokolik and Toon, 1999; Quijano et al., 2000; Haywood et al., 2011; Andrews et al., 2006). The HV and relative humidity (RH) were obtained from the hourly meteorological data. The surface albedo $R_{\mathrm{S}}$ of the desert surface has been reported in literature to be in the range of 0.3-0.35 (Quijano et al., 2000; Andreae et al., 2002; Mallet et al., 2009). The first author had recently measured surface albedo at different locations in the Kuwaiti desert and at different times of the year and found it to be 0.35 for most of the locations and times. The surface albedo was measured using an albedometer that was assembled from two pyrometers fixed back-to-back in order to measure the incoming solar flux and reflected solar flux. Since radiative forcing is highly dependent on accurate assessment of $R_{\mathrm{S}}$ (Tegen et al., 2010) and since $R_{\mathrm{S}}$ was not measured during the dust storm, radiative fluxes were calculated for both values of $R_{\mathrm{s}} ; 0.3$ and 0.35 . The SBDART model was executed for a midlatitude summer atmospheric profile using six streams for SW and LW DRF calculations. The total or net DRF were calculated as the sum of SW and LW forcing. The vertical distribution of dust aerosol concentration was estimated from Fig. 12. The dust height was set to $2 \mathrm{~km}$ and then dropped by a factor of 2 between 2 and $6 \mathrm{~km}$ and then by a factor of 500 between 6 and $10 \mathrm{~km}$.

\subsection{Results}

The DRF results for 26-27 March are stated in Table 4. The DRF of the atmosphere, $\mathrm{DRF}_{\mathrm{atm}}$, which is the difference between $\mathrm{DRF}_{\mathrm{TOA}}$ and $\mathrm{DRF}_{\text {surf }}$ is also stated. The DRF results stated in Table 4 show clearly that mineral dust aerosols had a major cooling effect on the TOA and surface level through the attenuation of incoming solar radiation and a minor heating effect due to LW absorption. The total effect had 
Table 4. Instantaneous shortwave and longwave DRF estimation for 26-27 March 2003 at two surface reflectances at 11:30 LT (+ 3 UTC).

\begin{tabular}{llrrrrr}
\hline & & \multicolumn{2}{c}{26 March } & & \multicolumn{2}{c}{27 March } \\
\cline { 3 - 4 } \cline { 6 - 7 } & & $R_{\mathrm{S}}=0.3$ & $R_{\mathrm{S}}=0.35$ & & $R_{\mathrm{S}}=0.3$ & $R_{\mathrm{S}}=0.35$ \\
\hline $\mathrm{SW}$ & DRF $_{\mathrm{TOOA}}$ & -95 & -70 & & -119 & -93 \\
$\left(\mathrm{Wm}^{-2}\right)$ & $\mathrm{DRF}_{\text {surf }}$ & -204 & -183 & & -218 & -195 \\
$\mathrm{LW}$ & $\mathrm{DRF}_{\mathrm{TOA}}$ & 11 & 10 & & 12 & 11 \\
$\left(\mathrm{Wm}^{-2}\right)$ & $\mathrm{DRF}_{\text {surf }}$ & 9 & 8 & & 10 & 9 \\
\hline $\mathrm{Total} \mathrm{DRF}$ & $\mathrm{DRF}_{\mathrm{o}, \mathrm{TOA}}$ & -84 & -60 & & -107 & -82 \\
$\left(\mathrm{Wm}^{-2}\right)$ & $\mathrm{DRF}_{\mathrm{o} \text {, surf }}$ & -195 & -175 & & -208 & -186 \\
& $\mathrm{DRF}_{\circ, \text { atm }}$ & 111 & 115 & & 107 & 104 \\
\hline
\end{tabular}

been cooling of TOA and surface levels but heating the atmosphere in between. On 26 March the SW DRF reached $-95 \mathrm{~W} \mathrm{~m}^{-2}$ at TOA and $-204 \mathrm{~W} \mathrm{~m}^{-2}$ at surface level for surface albedo of 0.3 and was reduced by $26 \%$ at TOA and $10 \%$ at surface level for surface albedo of 0.35 making it -70 and $-183 \mathrm{~W} \mathrm{~m}^{-2}$, respectively. The reduction in DRF at both TOA and surface level as the surface albedo increases is due to the enhancement of scattering with the surface (Liao and Sienfeld, 1998). On 27 March the SW DRF increased slightly, in the negative, due to the slight increase in AOT. However the LW contribution to DRF was almost invariant to the changes in surface albedo and very similar for both days of interest with an average of $11 \mathrm{~W} \mathrm{~m}^{-2}$ at TOA and $9 \mathrm{~W} \mathrm{~m}^{-2}$ at surface level. The negative forcing at both TOA and surface level had caused heating of the atmosphere by $111 \mathrm{~W} \mathrm{~m}^{-2}$ for $R_{\mathrm{S}}=0.3$ and $115 \mathrm{~W} \mathrm{~m}^{-2}$ for $R_{\mathrm{S}}=0.35$.

\subsection{Discussion}

Quantification of radiative forcing over the Arabian (Persian) Gulf has been quite scarce for regular dust loading and almost none for extreme dust loading. One study was conducted in the United Arab Emirates by Markowicz et al. (2008) to calculate the average aerosol diurnal surface forcing during the summer months of August and September 2004. They found the RF at surface level to be $-20 \mathrm{~W} \mathrm{~m}^{-2}$ when AOT was 0.45 and single scattering albedo was 0.93 at $500 \mathrm{~nm}$. Some studies had quantified RF caused by dust storms over the Indian subcontinent. For example Sharma et al. (2012) calculated RF over Patiala in India for 6 days of high dust loading $\left(\tau_{500}=1 \pm 0.51\right)$ and found the average $\mathrm{RF}$ to vary between -50 and $-100 \mathrm{~W} \mathrm{~m}^{-2}$ at surface level and -10 and $-25 \mathrm{~W} \mathrm{~m}^{-2}$ at TOA. In another study Prasad et al. (2007) calculated RF over Kanpur, India, and found the average RF at surface level to be -57.5 and $-13.5 \mathrm{~W} \mathrm{~m}^{-2}$ at TOA during the months of April and May where $\tau_{500}$ reached $1.44, \omega_{500}=0.92 \pm 0.03$ and $R_{\mathrm{S}}=0.2-0.23$. Similarly, Pandithurai et al. (2008) calculated RF over New Delhi, India, during the dusty season of March through June 2006 and found the net RF at surface level

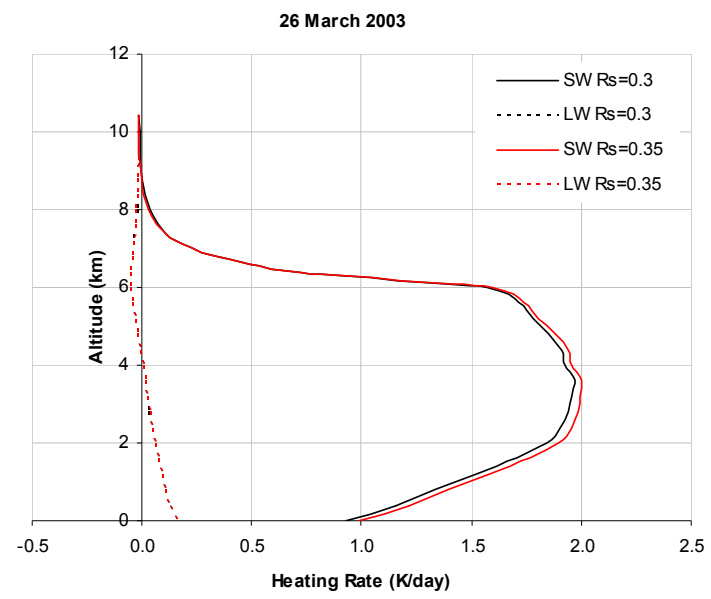

Fig. 13. SW and LW heating/cooling rate variations with altitude on 26 March for surface reflectivity of 0.3 and 0.35 . Most of the heating is well within the dust layer and drops sharply to zero above $6 \mathrm{~km}$, which is the upper boundary of the dust layer.

to increase from $-30 \mathrm{~W} \mathrm{~m}^{-2}$ for March to $-84 \mathrm{~W} \mathrm{~m}^{-2}$ for June whereas net RF at TOA increased from $-3.2 \mathrm{~W} \mathrm{~m}^{-2}$ for March to $43 \mathrm{~W} \mathrm{~m}^{-2}$ for June $\left(\omega_{500} \approx 0.84-0.74, \tau_{500} \approx 0.55-\right.$ 1.18). Mallet et al. (2009) investigated the effect of dust aerosols on the surface and TOA radiation budget as well as on surface temperature over western Africa. They found that during an intensive dust episode the SW radiation decreased at the surface by a regional mean of $-137 \mathrm{~W} \mathrm{~m}^{-2}$, which led to a reduction in surface temperature by $4^{\circ} \mathrm{C}$. This is quite in agreement with our results except that the radiative forcing calculated here is larger due to the instantaneous estimation over a very small region. They also found that TOA SW cooling dominated the net forcing and reached a regional mean of $-12 \mathrm{~W} \mathrm{~m}^{-2}$.

\subsection{Radiative heating rate}

Atmospheric heating/cooling rate, $\Delta T / \Delta t$ (in $\mathrm{K} \mathrm{day}^{-1}$ ), due to the interaction of SW and LW radiation by mineral dust have been simulated by SBDART following the equation

$$
\frac{\Delta T}{\Delta t}=\frac{-1}{\rho_{\mathrm{air}} \cdot C_{\mathrm{p}}} \cdot \frac{\Delta F_{\mathrm{net}}}{\Delta z},
$$

where $\rho_{\text {air }}$ is air density, which equals $1.17 \mathrm{~kg} \mathrm{~m}^{-3}$, and $C_{\mathrm{p}}$ is specific heat of dry air, which equals $1004.67 \mathrm{~J} \mathrm{~kg}^{-1} \mathrm{~K}^{-1}$. The factor $\Delta F_{\text {net }} / \Delta z$ is calculated as the ratio between the net flux $\Delta F$ leaving a layer of atmosphere of thickness $\Delta z$ and the thickness of that layer (Carlson and Benjamin, 1980; Quijano et al., 2000; Petty, 2006). Net heating/cooling rates were calculated in LW and SW bands as the difference in heating/cooling between the dust-laden atmosphere of 26 March and a hypothetically dust-free atmosphere. Figure 13 plots the variation in heating/cooling with altitude for surface reflectivity of 0.3 and 0.35 . The heating/cooling 
profile for 27 March is quite similar to that of 26 March and hence omitted. The heating of the atmosphere within the dust layer is associated primarily with SW absorption by mineral dust. However radiative flux adjustments in response to the exerted radiative forcing can alter the heat distribution substantially on a daily or even hourly timescale (Heinold et al., 2008; Spyrou et al., 2013). The heating rate reached a maximum of $2 \mathrm{Kday}^{-1}$ at atmospheric layers of 3-5 km (Fig. 13). Although heating rates are affected by the reflectivity of the underlying surface (Bierwirth et al., 2009) it is found here that the difference in heating/cooling rates between the two surfaces is quite small. However, emission in the LW radiation caused a declining heating profile at the first $4 \mathrm{~km}$ with a maximum of $0.2 \mathrm{~K} \mathrm{day}^{-1}$ at surface level. This slight heating is due to the abundance of coarse-sized dust particles near the surface, which through a relatively small but yet significant amount of absorption tend to heat the atmospheric layers adjacent to the surface. Above $4 \mathrm{~km}$ the LW radiative forcing switched to cooling due to the dominance of fine dust particles and reached a maximum of $-0.1 \mathrm{~K} \mathrm{day}^{-1}$ at $6 \mathrm{~km}$. Beyond $7 \mathrm{~km}$ both SW and LW heating/cooling rates diminished. This profile of heating/cooling rate mirrors the SKIRON simulation of the dust vertical profile (Fig. 12) whereby the coarse-sized dust particles are concentrated in the first $3 \mathrm{~km}$ and the fine dust particles are elevated to $6 \mathrm{~km}$. Comparable results were obtained by Mohalfi et al. (1998), who investigated heating rates during dust outbreaks over Saudi Arabia using the Florida State University limited area model. They found that dust particles had a significant effect over the SW radiation, which caused the heating rate to reach almost $2 \mathrm{~K} \mathrm{day}^{-1}$ at about $6 \mathrm{~km}$ and $3 \mathrm{~K} \mathrm{day}^{-1}$ at about $8 \mathrm{~km}$. Similarly Mallet et al. (2009) investigated the heating rate over western Africa and found that the maximum SW heating rate occurred within the dust layer with values between 4 and $7 \mathrm{Kday}^{-1}$ and LW heating rates between -1 and $0.2 \mathrm{~K} \mathrm{day}^{-1}$.

\section{Summary and conclusion}

The Arabian Peninsula is one of the five major sources of mineral dust around the globe. Yet only a few studies have been conducted on the characterization of dust properties of the Arabian Peninsula and virtually no study exists, to the best knowledge of the authors, on the radiative impact of a dust storm in the Arabian Peninsula. In this case study we examine the optical, physical and radiative properties of an extreme case of instantaneous loading of the lower troposphere by dust aerosols caused by a shamal dust storm. A low-pressure system moved from the northern Mediterranean through northern Africa into northern Iraq, Baghdad and then reached Kuwait on 26 March 2003 as a dust storm at 07:00 LT. The severity of the dust storm not only reduced visibility to about $200 \mathrm{~m}$ but also left a thick suspension of fine dust in the lower troposphere for the following $24 \mathrm{~h}$. Dust concentrations reached $4800 \mu \mathrm{g} \mathrm{m}^{-3}$ on 26 March and fluctuated around $1000 \mu \mathrm{g} \mathrm{m}^{-3}$ throughout the following day. Ground-based measurements of AOT reached 3.617 on 26 March and 4.17 on 27 March with the corresponding Ångstrom coefficient $\alpha_{870 / 440}$ dropping to -0.0234 and -0.0318 respectively reflecting the dominance of coarse-sized particles. MODIS-retrieved AOD with the Deep Blue algorithm over the area of Kuwait exceeded 0.8 on both days of interest. MODIS-retrieved AOD field and TOMS-retrieved AI over the Arabian Peninsula revealed two main source regions of dust transport over Kuwait: the lower Mesopotamian region in the north and the Rub'al Khali region in the south. Dust transport from these two source regions added to the intensity of the fallen dust over Kuwait and expanded the resultant rising dust on 27 March to encompass the middle to eastern parts of the Arabian Peninsula. The atmospheric model SKIRON was employed to estimate the vertical profile of the dust layer. It was found that the whole dust layer had reached about $6 \mathrm{~km}$ above surface level but the bulk of the coarse-sized dust particles were concentrated in the lower $3 \mathrm{~km}$. The instantaneous impact of the dust layer on the radiative flux was calculated at TOA and surface level for both SW and LW components of the electromagnetic spectrum using the atmospheric transfer model SBDART. The net RF was dominated by the SW cooling at TOA due to the backscattering of incoming solar radiation and cooling at surface level due to the attenuation of solar radiation by the dust layer. Radiative forcing was calculated for two characteristic surface albedos of the desert environment, $R_{\mathrm{S}}=0.3$ and $R_{\mathrm{S}}=0.35$. Net RF on 26 March reached $-60 \mathrm{~W} \mathrm{~m}^{-2}$ at TOA and $-175 \mathrm{Wm}^{-2}$ at surface level for $R_{\mathrm{S}}=0.35 ;-84 \mathrm{~W} \mathrm{~m}^{-2}$ for TOA and $-195 \mathrm{~W} \mathrm{~m}^{-2}$ for surface level for $R_{\mathrm{S}}=0.3$. Radiative forcing on $27 \mathrm{March}$ was slightly higher due to the increase in AOT. Finally, the heating/cooling rate in the SW and LW bands were investigated. Heating rate was dominant due to $\mathrm{SW}$ absorption by dust aerosols and reached a peak value of $2 \mathrm{~K} \mathrm{day}^{-1}$ at atmospheric layers located between 3 and $5 \mathrm{~km}$ from ground level. However it was found that the abundance of coarse-sized dust particles enhanced LW absorption and added a small amount of heating, maximum $0.2 \mathrm{~K} \mathrm{day}^{-1}$, at the atmospheric layers adjacent to ground level. This heating decreased rapidly for higher altitude as finer particles replaced coarser ones. At $4 \mathrm{~km}$ LW heating switched to cooling and reached a maximum value of $-0.1 \mathrm{Kday}^{-1}$ at $6 \mathrm{~km}$. Above $7 \mathrm{~km}$ both SW and LW heating/cooling rates were reduced to zero. The heating/cooling profile mirrored the SKIRON simulation of dust profiles.

Acknowledgements. This work was supported by PAAET funds BE_01_005, BE_10_45 and the Kuwait Foundation for the Advancement of Science (KFAS) fund 2009-1401-01.

Analyses and visualizations used in this paper were produced with the Giovanni online data system, developed and maintained 
by the NASA Goddard Earth Sciences (GES) Data and Information Services Center (DISC).

Michael Bergun and Giorgi de Siaara for their helpful discussions on radiative forcing.

Nabeel Wilf for providing references.

Andrew Sayer, H. El-Askary and two anonymous referees for their valuable suggestions.

Mary Winkler for revising the manuscript.

Edited by: N. Mihalopoulos

\section{References}

Abdi Vishkaee, F., Flamant, C., Cuesta, J., Flamant, P., and Khalesifard, H. R.: Multiplatform observations of dust vertical distribution during transport over northwest Iran in the summertime, J. Geophys. Res., 116, D05206, doi:10.1029/2010JD014573, 2011.

Achudume, A. C. and Oladipo, B. O.: Effects of dust storm on health in the Nigerian environment, Biol. Med., 1, 21-27, 2009.

Aerodrome Reports and Forecast, a user handbook to the codes, WMO 782, 4th Edn., Secretariat of World Meteorological Organization, Geneva, Switzerland, 2005.

Ahn, H. J., Park, S. U., and Chang, L. S.: Effect of Direct Radiative Forcing of Asian Dust on the Meteorological Fields in East Asia during an Asian Dust Event Period, J. Appl. Meteorol. Clim., 46, 1655-1681, 2007.

Alizadeh Choobari, O., Zawar-Reza, P., and Sturman, A.: Low level jet intensification by mineral dust aerosols, Ann. Geophys., 31, 625-632, doi:10.5194/angeo-31-625-2013, 2013.

Alpert, P., Kishcha, P., Shtivelman, A., Krichak, S. O., and Joseph, J. H.: Vertical distribution of Saharan dust based on 2.5-year model predictions, Atmos. Res., 70, 109-130, 2004.

Anderson, J., Hardy, E., Roach, J., and Witmer, R.: A land use and land cover classification system for use with remote sensing data, US Geol. Prof. Pap. 964, US Gov. Print. Off., Washington, D.C., 1976.

Andreae, T. W., Andreae, M. O., Ichoku, C., Karnieli, A., and Orlovsky, L.: Light scattering by dust and anthropogenic aerosol at a remote site in the Negev desert, Israel, J. Geophys. Res., 107, 4008, doi:10.1029/2001JD900252, 2002.

Andrews, E., Sheridan, P. J., Fiebig, M., McComiskey, A., Ogren, J. A., Arnott, P., Covert, D., Elleman, R., Gasparini, R., Collins, D., Jonsson, H., Schmid, B., and Wang, J.: Comparison of methods for deriving aerosol asymmetry parameter, J. Geophys. Res., 111, D05S04, doi:10.1029/2004JD005734, 2006.

Ansmann, A., Petzold, A., Kandler, K., Tegen, I., Wendisch, M., Muller, D., Weinzierl, B., Muller, T., and Heintzenberg, J.: Saharan Mineral Dust Experiments SAMUM-1 and SAMUM-2: What have we learned?, Tellus B, 63, 403-429, doi:10.1111/j.1600-0889.2011.00555.x, 2011a.

Atkinson R.: In the Company of Soldiers, Henry Holt and Company, New York, 337 pp., 2004.

Berk, A., Bernstein, L. S., and Robertson, D. C.: MODTRAN: a moderate resolution model for LOWTRAN 7, GLTR-89-0122, Air Force Geophys. Lab., Hanscom AFB, MA, 38 pp., 1989.
Bierwirth, E., Wendisch, M., Ehrlich, A., Heese, B., Tesche, M., Althausen, D., Schladitz, A., Müller, D., Otto, S., Trautmann, T., Dinter, T., Von Hoyningen-Huene, W., and Kahn, R.: Spectral surface albedo over Morocco and its impact on radiative forcing of Saharan dust, Tellus B, 61, 252-269, doi:10.1111/j.16000889.2008.00395.x, 2009.

Carbo, P., Krom, M. D., Homoky, W. B., Benning, L. G., and Herut, B.: Impact of atmospheric deposition on $\mathrm{N}$ and $\mathrm{P}$ geochemistry in the southeastern Levantine basin, Deep-Sea Res. Pt. II, 52, 3041-3053, 2005.

Carlson, T. N. and Benjamin S.: Radiative heating rates for Sahara dust, J. Atmos. Sci., 37, 193-213, 1980.

Chen, S., Kuo, Y., Ming, W., and Ying, H.: The effect of dust radiative heating on low-level frontogenesis, J. Atmos. Sci., 52, 14141420, 1994.

Chylek, P. and Coakley, J. A.: Aerosols and Climate, Science, 183, 75-77, 1974.

Costa, M. J., Sohn, B. J., Levizzani, V., and Silva, A. M.: Radiative Forcing of Asian Dust determined from the Synergized GOME and GMS Satellite Data - A Case Study, J. Meteorol. Soc. Jpn., 84, 85-95, 2006.

D'Almeida, G. A.: On the variability of desert aerosol radiative characteristics, J. Geophys. Res., 92, 3017-3026, 1987.

De Villiers, M. P. and Van Heerden, J.: Dust Storms and dust at Abu Dhabi international airport, Weather, 62, 339-343, 2007.

Di Biagio, C., Di Sarra, A., and Meloni, D.: Large atmospheric shortwave radiative forcing by Mediterranean aerosols derived from simultaneous ground-based and spaceborne observations and dependence on the aerosol type and single scattering albedo, J. Geophys. Res., 115, D10209, doi:10.1029/2009JD012697, 2010.

Di Sarra, A., Pace, G., Meloni, D., De Silvestri, L., Piacentino, S., and Monteleone, F.: Surface shortwave radiative forcing of different aerosol types in the central Mediterranean, Geophys. Res. Lett., 35, L02714, doi:10.1029/2007GL032395, 2008.

El-Askary, H., Sarkar, S., Kafatos, M., and El-Gazawi, T.: A Multi-Sensor Approach to Dust Storm Monitoring over the Nile Delta, IEEE T. Geosci. Remote, 41, 2386-2391, doi:10.1109/TGRS.2003.817189, 2003.

Formenti, P., Schütz, L., Balkanski, Y., Desboeufs, K., Ebert, M., Kandler, K., Petzold, A., Scheuvens, D., Weinbruch, S., and Zhang, D.: Recent progress in understanding physical and chemical properties of African and Asian mineral dust, Atmos. Chem. Phys., 11, 8231-8256, doi:10.5194/acp-11-8231-2011, 2011.

Gao, T., Su, L., Ma, Q., Li, H., Li, X., and Yu, X.: Climatic analyses on increasing dust storm frequency in the springs of 2000 and 2001 in inner Mongolia, Int. J. Climatol., 23, 1743-1755, 2003.

Giles, J.: The dustiest place on Earth, Nature, 434, 816-819, 2005.

Gillette, D. A.: Fine particle emissions due to wind erosion, Trans. Am. Soc. Agric. Eng., 20, 891-897, 1977.

Ginoux, P. and Torres O.: Empirical TOMS index for dust aerosol: Applications to model validation and source characterization, J. Geophys. Res., 108, 4534-4554, doi:10.1029/2003JD003470, 2003.

Ginoux, P., Prospero, J., Gill, T., Hsu, N., and Zhao, M.: Globalscale attribution of anthropogenic and natural dust sources and their emission rates based on MODIS Deep Blue aerosol products, Rev. Geophys., 50, RG3005, doi:10.1029/2012RG000388, 2012 . 
Gobeli, D., Schloesser, H., and Pottberg, T.: Met One Instruments BAM-1020 Beta Attenuation Mass Monitor US-EPA PM 2.5 Federal Equivalent Method Field Test Results, A-485-AWMA, Met One Instruments Incorporated, Grants Pass, OR, USA, 11 pp., 2008.

Goudie, A. S.: Dust Storms: Recent developments, J. Environ. Manage., 90, 89-94, 2009.

Goudie, A. S. and Middleton, N. J.: The changing frequency of dust storms through time, Climatic Change, 20, 197-225, 1992.

Goudie, A. S. and Middleton, N. J.: Saharan dust storms: nature and consequences, Earth-Sci. Rev., 56, 179-204, 2001.

Goudie, A. S. and Middleton, N. J.: Desert Dust in the Global System, Springer, Heidelberg, 2006.

Griffin, D.: Atmospheric movement of microorganisms in clouds of desert dust and implications for human health, Clin. Microbiol. Rev., 20, 459-477, 2007.

Griffin, D. and Kellogg, C.: Dust Storms and Their Impact on Ocean and Human Health: Dust in Earth's Atmosphere, EcoHealth, 1, 284-295, 2004.

Haywood, J. and Boucher, O.: Estimates of Radiative Forcing, Rev. Geophys., 38, 513-543, 2000.

Haywood, J. M., Johnson, B. T., Osborne, S. R., Baran, A. J., Brooks, M., Milton, S. F., Mulcahy, J., Walters, D., Allan, R. P., Klaver, A., Formenti, P., Brindley, H. E., Christopher, S., and Gupta, P.: Motivation, rationale and key results from the GERBILS Saharan dust measurement campaign, Q. J. Roy. Meteorol. Soc., 137, 1106-1116, doi:10.1002/qj.797, 2011.

Heinold, B., Tegen, I., Schepanski, K., and Hellmuth, O.: Dust radiative feedback on Saharan boundary layer dynamics and dust mobilization, Geophys. Res. Lett., 35, L20817, doi:10.1029/2008GL035319, 2008.

Herut, B., Zohary, T., Krom, M. D., Mantoura, F. R., Pitta, P., Psarra, S., Rassoulzadegan, F., Tanaka, T., and Thingstad T. F.: Response of East Mediterranean surface water to Saharan dust: On-board microcosm experiment and field observation, DeepSea Res. Pt. II, 52, 3024-3040, 2005.

Hsu, N., Tsay, S., King, M., and Herman, J.: Aerosol properties over bright-reflecting source regions, IEEE T. Geosci. Remote, 42, 557-569, 2004.

Hsu, N., Tsay S., King, M., and Herman, J.: Deep Blue retrievals of Asian aerosol properties during ACE-Asia, IEEE T. Geosci. Remote, 44, 3180-3195, 2006.

Ichoku, C., Chu, D. A., Mattoo, S., Kaufman, Y. J., Remer, L. A., Tanré, D., Slutsker, I., and Holben, B. N.: A spatio-temporal approach for global validation and analysis of MODIS aerosol products, Geophys. Res. Lett., 29, 8006, doi:10.1029/2001g1013206, 2002.

Ichoku, C., Remer, L., and Eck, T.: Quantitative evaluation and intercomparison of morning and afternoon Moderate Resolution Imaging Spectroradiometer (MODIS) aerosol measurements from Terra and Aqua, J. Geophys. Res., 110, D10S03, doi:10.1029/2004JD004987, 2005.

IPCC - Intergovernmental Panel on Climate Change: Changes in atmospheric constituents and radiative 5 forcing: Climate change: the physical science basis, Cambridge University Press, New York, USA, and Cambridge, UK, 2007.

Janjic, Z. I.: Nonlinear advection schemes and energy cascade on semi-staggered grids, Mon. Weather Rev., 112, 1234-1245, 1984.
Jickells, T. D., An, Z. S., Andersen, K. K., Baker, A. R., Bergametti, G., Brooks, N., Cao, J. J., Boyd, P. W., Duce, R. A., Hunter, K. A., Kawahata, H., Kubilay, N., laRoche, J., Liss, P. S., Mahowald, N., Prospero, J. M., Ridgwell, A. J., Tegen, I., and Torres, R.: Global iron connections between desert dust, ocean biogeochemistry, and climate, Science, 308, 67-71, 2005.

Kallos, G., Nickovic, S., Jovic, D., Kakaliagou, O., Papadopoulos, A., Misirlis, N., Boukas, L., and Mimikou, N.: The ETA model operational forecasting system and its parallel implementation, 30 Proceedings of the 1st Workshop on Large-Scale Scientific Computations, 7-11 June 1997, Varna, Bulgaria, 15 pp., 1997.

Kallos, G., Papadopoulos, A., Katsafados, P., and Nickovic, S.: Transatlantic Saharandust transport: Model simulation and results, J. Geophys. Res., 111, D09204, doi:10.1029/2005JD006207, 2006.

Kaskaoutis D. G., Kambezidis, H. D., Nastos, P. T., and Kosmopoulos, P. G.: Study on an intense dust storm over Greece, Atmos. Envriron., 42, 6884-6896, 2008.

Kaufman, Y. J., Wald, A. E., Remer, L. A., Bo-Cai, G., Rong-Rong, L., and Flynn, L.: The MODIS 2.1-mum channel-correlation with visible reflectance for use in remote sensing of aerosol, IEEE T. Geosci. Remote, 35, 1286-1298, 1997.

King, M., Kaufman, Y., Tanré, D., and Nakajima, T.: Remote sensing of tropospheric aerosols from space: Past, present and future, B. Am. Meteorol. Soc., 80, 2229-2259, 1999.

Kneizys, F. X., Shettle, E. P., Gallery, W. O., Chetwynd, J. H., Abreu, L. W., Selby, J. E. A., Clough, S. A., and Fenn, R. W.: Atmospheric transmittance/radiance: Computer code LOWTRAN 6, Rep. AFGL-TR-83-0187, Air Force Geophysical Laboratory, Hanscom Air Force Base, MA, 200 pp., 1983.

Kutiel, H. and Fruman, F.: Dust storms in the middle east: sources of origin and their temporal characteristics, Indoor. Buil. Environ., 12, 419-426, 2003.

Lemaître, C., Flamant, C., Cuesta, J., Raut, J.-C., Chazette, P., Formenti, P., and Pelon, J.: Radiative heating rates profiles associated with a springtime case of Bodélé and Sudan dust transport over West Africa, Atmos. Chem. Phys., 10, 8131-8150, doi:10.5194/acp-10-8131-2010, 2010.

Leski, T. A., Malanoski, A. P., Gregory, M. J., Lin, B., and Stenger, D. A.: Application of a Broad-Range Resequencing Array for Detection of Pathogens in Desert Dust Samples from Kuwait and Iraq, Appl. Environ. Microbiol., 77, 4285-4292, 2011.

Levy, R. C., Remer, L. A., Martins, J. V., Kaufman, Y. J., Plana-Fattori, A., Redemann, J., and Wenny, B.: Evaluation of the MODIS Aerosol Retrievals over Ocean and Land during CLAMS, J. Atmos. Sci., 62, 974-992, doi:10.1175/JAS3391.1, 2005.

Levy, R. C., Remer, L. A., Kleidman, R. G., Mattoo, S., Ichoku, C., Kahn, R., and Eck, T. F.: Global evaluation of the Collection 5 MODIS dark-target aerosol products over land, Atmos. Chem. Phys., 10, 10399-10420, doi:10.5194/acp-10-10399-2010, 2010.

Li, F., Vogelmann, A. M., and Ramanathan, V.: Dust aerosol radiative forcing measured from space over the Western Africa, J. Climate, 17, 2558-2571, 2004.

Lio, H. and Seinfeld, J. H.: Radiative forcing by mineral dust aerosols: sensitivity to key variables, J. Geophys. Res., 103, 31637-31645, 1998.

Lyles, L.: Basic wind erosion processes, Agr. Ecosyst. Environ., 22/23, 91-101, 1988 
Mahowald, N. M., Baker, A. R., Bergametti, G., Brooks, N., Duce, R. A., Jickells, T. D., Kubilay, N., Prospero, J. M., and Tegen, I.: Atmospheric global dust cycle and iron inputs to the ocean, Global Biogeochem. Cy., 19, GB4025, doi:10.1029/2004GB002402 2005.

Mallet, M., Tulet, P., Serça, D., Solmon, F., Dubovik, O., Pelon, J., Pont, V., and Thouron, O.: Impact of dust aerosols on the radiative budget, surface heat fluxes, heating rate profiles and convective activity over West Africa during March 2006, Atmos. Chem. Phys., 9, 7143-7160, doi:10.5194/acp-9-7143-2009, 2009.

Markowicz, K. M., Flatau, P. J., Remiszewska, J., Witek, M., Reid, E. A., Reid, J. S., Bucholtz, A., and Holben, B.: Observations and Modeling of the Surface Aerosol Radiative Forcing during $\mathrm{UAE}^{2}$, J. Atmos. Sci., 65, 2877-2891, 2008.

Marshall, S. F., Covert, D. S., and Charlson, R. J.: Relationship between asymmetry parameter and hemispheric backscatter ratio: implications for climate forcing by aerosols, Appl. Optics, 34, 6306-6311, 1995.

McConnell, C. L., Highwood, E. J., Coe, H., Formenti, P., Anderson, B., Osborne, S., Nava, S., Desboeufs, K., Chen, G., and Harrison, M. A. J.: Seasonal variations of the physical and optical characteristics of Saharan dust: Results from the Dust Outflow and Deposition to the Ocean (DODO) experiment, J. Geophys. Res., 113, D14S05, doi:10.1029/2007jd009606, 2008.

Mesinger, F.: A blocking technique for representation of mountains in atmospheric models, Riv. Meteorol. Aeronaut., 44, 195-202, 1984.

Middleton, N. J.: Dust storms in the Middle East, J. Arid. Environ., 10, 83-96, 1986.

Miller, D. A. and White, R. A.: A conterminous United States multilayer soil characteristics data set for regional climate and hydrology modeling, Earth Interact., 2, 1-26, 1998.

Mohalfi, S., Bedi, H. S., Krishnamurti, T. N., and Cocke, S. D.: Impact of short wave radiative effects of dust aerosols on the summer season heat low over Saudi Arabia, Mon. Weather Rev., 126, 3153-3168, 1998.

Notaro, M., Alkolibi, F., Fadda, E., and Bakhrjy, F.: Trajectory analysis of Saudi Arabian dust storms, J. Geophys. Res.-Atmos., 118, 6028-6043, doi:10.1002/jgrd.50346, 2013.

Osborne, S. R., Johnson, B. T., Haywood, J. M., Baran, A. J., Harrison, M. A. J., and McConnell, C. L.: Physical and optical properties of mineral dust aerosol during the Dust and Biomass-burning Experiment, J. Geophys. Res., 113, D00C03, doi:10.1029/2007jd009551, 2008.

Pandithurai, G., Dipu, S., Dani, K. K., Tiwari, S., Bisht, D. S., Devara, P. C. S., and Pinker, R. T.: Aerosol radiative forcing during dust events over New Delhi, India, J. Geophys. Res., 113, D13209, doi:10.1029/2008JD009804, 2008.

Park, S., Ahn, H., and Park, M.: Direct shortwave radiative forcing of the Asian dust aerosol on dust emission, Theor. Appl. Climatol., 101, 179-190, 2010.

Pérez, C., Nickovic, S., Baldasano, J. M., Sicard, M., Rocadenbosch, F., and Achorro, V. E.: A long Saharan dust event over the western Mediterranean: Lidar, Sunphotometer observations, and regional dust modeling, J. Geophys. Res., 111, D15214, doi:10.1029/2005JD006579, 2006.

Perrone, T. J.: Winter Shamal in the Persian Gulf, Technical Report, Naval Environmental Prediction Research Facility, Monterey, California, 1979.
Petty, G. M.: A First Course In Atmospheric Radiation, Sundog Publishing, 458 pp., 2006.

Prasad, A. K. and Singh, R. P.: Changes in aerosol parameters during major dust storm events (2001-2005) over Indo-Gangetic plains using AERONET and MODIS data, J. Geophys. Res., 112, D09208, doi:10.1029/2006JD007778, 2007.

Prospero, J. M., Ginoux, P., Torres, O., Nicholson, S. E., and Gill, T. E.: Environmental characterization of global sources of atmospheric soil dust identified with the Nimbus-7 Total Ozone Mapping Spectrometer (TOMS) absorbing aerosol product, Rev. Geophys. 40, 1002, doi:10.1029/2000RG000095, 2002.

Quijano, A. L., Sokolik, I. N., and Toon, O. B.: Radiative heating rates and direct radiative forcing by mineral dust in cloudy atmospheric conditions, J. Geophys. Res., 105, 12207-12219, 2000.

Rashki, A., Kaskaoutis, D. G., de Rautenbach, C. J. W., Eriksson, P. G., Qiang, M., and Gupta, P.: Dust storms and their horizontal dust loading in the Sistan region, Iran, Aeolian Res., 5, 51-62, 2012.

Ravi, S., Breshears, D. D., Huxman, T. E., and D’Odorico, P.: Land degradation in drylands: Interactions among hydrologic-aeolian erosion and vegetation dynamics, Geomorphology, 116, 236245, 2010.

Remer, L. A., Kaufman, Y. J., Tanré, D., Mattoo, S., Chu, D. A., Martins, J. V., Li, R.-R., Ichoku, C., Levy, R. C., Kleidman, R. G., Eck, T. F., Vermote, E., and Holben, B. N.: The MODIS Aerosol Algorithm, Products, and Validation, J. Atmos. Sci., 62, 947-973, doi:10.1175/JAS3385.1, 2005.

Remer, L. A., Kleidman, R. G., Levy, R. C., Kaufman, Y. J., Tanré, D., Mattoo, S., Martins, J. V., Ichoku, C., Koren, I., Yu, H., and Holben, B. N.: Global aerosol climatology from the MODIS satellite sensors, J. Geophys. Res., 113, D14S07, doi:10.1029/2007jd009661, 2008.

Rezazadeh, M., Irannejad, P., and Shao, Y.: Climatology of the Middle East dust events, Aeolian Res., 10, 103-109, 2013.

Ricchiazzi, P., Yang, S., Gautier, C., and Sowle, D.: SBDART: A research and teaching software tool for plane-parallel radiative transfer in the Earth's atmosphere, B. Am. Meteorol. Soc., 79, 2101-2114, 1998.

Sabbah, I., Ichoku, C., Kaufman, Y. J., and Remer, L.: Full year cycle of desert dust spectral optical thickness and precipitable water vapor over Alexandria Egypt, J. Geophys. Res., 106, 1830518316, 2001.

Saeed, T. and Al-Dashti, H.: Optical and physical characterization of "Iraqi freedom" dust storm, a case study, Theor. Appl. Climatol., 104, 123-137, 2010.

Seinfeld, J. H. and Pandis, S. N.: Atmospheric Chemistry and Physics: From Air Pollution to Climate Change, John Wiley, New York, 1326 pp., 1998.

Sharma, D., Singh, D., and Kaskaoutis, D. G.: Impact of Two Intense Dust Storms on Aerosol Characteristics and Radiative Forcing over Patiala, Northwestern India, Adv. Meteorol., doi:10.1155/2012/956814, in press, 2012.

Simonson, R. W.: Airborne dust and its significance to soils, Geoderma, 65, 1-43, 1995.

Sokolik, I. N. and Toon, O. B.: Incorporation of mineralogical composition into models of the radiative properties of mineral aerosol from UV to IR wavelengths, J. Geophys. Res., 104, 9423-9444, 1999. 
Spyrou, C., Mitsakou, C., Kallos, G., Louka, P., and Vlastou, G.: An improved limited area model for describing the dust cycle in the atmosphere, J. Geophys. Res., 115, D17211, doi::10.1029/2009JD013682, 2010.

Spyrou, C., Kallos, G., Mitsakou, C., Athanasiadis, P., Kalogeri, C., and Iacono, M. J.: Modeling the radiative effects of desert dust on weather and regional climate, Atmos. Chem. Phys., 13, 54895504, doi:10.5194/acp-13-5489-2013, 2013.

Stamnes, K., Tsay, S. C., Wiscombe, W., and Jayaweera, K.: Numerically stable algorithm for discrete-ordinate-method radiative transfer in multiple scattering and emitting layered media, Appl. Optics, 27, 2502-2509, 1988.

Stefanski, R. and Sivakumar, M. V. K.: Impacts of sand and dust storms on agriculture and potential agricultural applications of a SDSWS, IOP Conf. Ser.: Earth Environ. Sci., 7, 012016, doi:10.1088/1755-1307/7/1/012016, 2009.

Stephens, G. L.: Remote sensing of the lower atmosphere, Oxford University Press, 523 pp., 1994.

Swap, R., Garstang, M., Greco, S., Talbot, R., and Kallberg, P.: Sahara dust in the Amazon basin, Tellus B, 44, 133-149, 1992.

Tanré, D., Haywood, J., Pelon, J., Léon, J. F., Chatenet, B., Formenti, P., Francis, P., Goloub, P., Highwood, E. J., and Myhre, G.: Measurement and modeling of the Saharan dust radiative impact: Overview of the Saharan Dust Experiment (SHADE), J. Geophys. Res., 108, 8574-8586, doi:10.1029/2002jd003273, 2003.

Tegen, I. and Lacis, A. A.: Modeling of particle influence on the radiative properties of mineral dust aerosol, J. Geophys. Res., 101, 19237-19244, 1996.

Tegen, I., Bierwirth, E., Heinold, B., Helmert, J., and Wendisch, M.,: Effect of measured surface albedo on modeled Saharan dust solar radiative forcing, J. Geophys. Res., 115, D24312, doi:10.1029/2009JD013764, 2010.
Torres, O., Bhartia, P. K., Herman, J. R., Ahmad, Z., and Gleason, J.: Derivation of aerosol properties from satellite measurements of backscattered ultraviolet radiation: Theoretical basis, J. Geophys. Res., 103, 17099-17110, doi:10.1029/98JD00900, 1998.

Tsolmon, R., Ochirkhuyag, L., and Sternberg, T.: Monitoring the source of trans-national dust storms in north east Asia, Int. J. Digit. Earth, 1, 119-129, 2008.

Washington, R., Todd, M., Middleton, N. J., and Goudie, A. S.: Dust-Storm source areas determined by the Total Ozone Monitoring Spectrometer and surface observations, An. Amer. Geogr., 93, 297-313, 2003.

Wilkerson, W. D.: Dust and sand forecasting in Iraq and adjoining countries, Technical Report, Air Weather Services, Scott AFB, Illinois, 1991.

Wilson, R. and Spengler, J.: Particles in Our Air: Concentrations and Health Effects, Harvard Univ. Press., Cambridge, MA, 254 pp., 1996.

Xu, J., Bergin, M. H., Greenwald, R., and Russell, P. B.: Direct aerosol radiative forcing in the Yangtze delta region of China: Observation and model estimation, J. Geophys. Res., 108, 40604072, 2003.

Xuana, J., Sokolik, I. N., Hao, J., Guo, F., Mao, H., and Yang, G.: Identification and characterization of sources of atmospheric mineral dust in East Asia, Atmos. Environ., 38, 6239-6252, 2004.

Youlin, Y., Squires, V. R., and Qu, L.: Global alarm: Dust and sandstorms from the world's drylands, UN, Bejing, 325 pp., 2002.

Zender, C. S., Bian, H., and Newman, D.: Mineral Dust Entrainment and Deposition (DEAD) model: Description and 1990s dust climatology, J. Geophys. Res., 108, D144416, doi:10.1029/2002JD002775, 2003. 